INNOVATIVE AND

APPLIED RESEARCH

IN BIOLOGY

\title{
Proceedings
}

Volume 3 


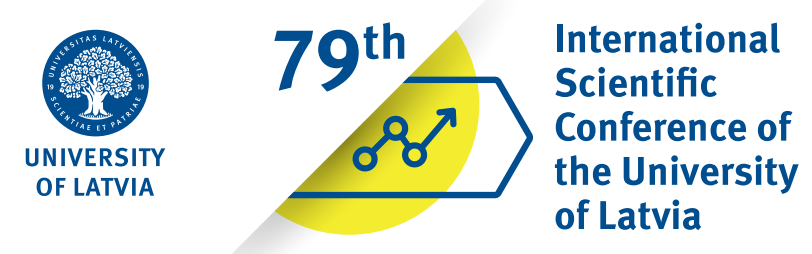

\section{INNOVATIVE AND APPLIED RESEARCH IN BIOLOGY}

\section{Proceedings}

Volume 3 
$79^{\text {th }}$ International Scientific Conference of the University of Latvia. Institute of Biology. Innovative and Applied Research in Biology. Proceedings. Volume 3. Jankevica, L. (comp.). Riga, 2021.55 p.

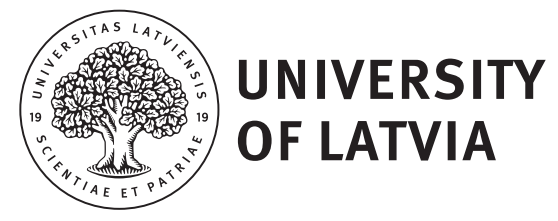

\title{
International Scientific Committee
}

\author{
Dr. biol. Liene Auniņa (LU, Latvia) \\ Dr. biol. İzaks Rašals (LU, Latvia) \\ Dr. biol. Andis Karlsons (LU, Latvia) \\ Dr. biol. Dalius Butkauskas (Nature Research Centre, Lithuania) \\ Dr. biol. Anita Osvalde (LU, Latvia) \\ Dr. biol. Dmitry Telnov (The Natural History Museum, UK) \\ Dr. biol. Ineta Salmane (LU)
}

Compiler: Dr. biol. Līga Jankevica

Editors: Līga Jankevica, Liene Auniņa

Technical editor: Gita Kḷaviṇa

Layout: Ineta Priga

(C) Authors of abstracts, 2021

(c) University of Latvia, 2021

ISBN 978-9934-18-787-2 (PDF)

https://doi.org/10.22364/iarb.2021 


\section{Content}

Elmīra Boikova, Lelde Eṇǵele, Vita Līcīte, Uvis Suško

Protected water habitats in the landscape area "Augšdaugava"

Nikole Krasṇevska, Dalius Butkauskas,

Natalia Samokhvalova, Andra Miķelsone, Alesia Kruchonok,

Dace Grauda

Study of cloudberry Rubus chamaemorus L. genetic diversity in

Latvia and Belarus based on different molecular marker systems

Sandra Dombrovska, Dace Grauda, Andra Mikselsone

Trifolium repens $\mathrm{L}$. genetic changes after UV-B radiation on

the base of retrotransposon movement

Sergejs Koḷesovs, Kristaps Neiberts, Maija Rukliša,

Pāvels Semjonovs

Bacterial cellulose production on whey - an overview of prospects

Dalius Butkauskas, Dace Grauda, Andra Miḳelsone,

Dāvis Rašals, Rimantas Petrošius, Kamilè Kazlauskaitė

Experimental evidence of the impact of low-frequency

electromagnetic field on the reproductive success of fruit fly

Drosopfila melanogaster and its potential to generate new point

mutations at some candidate genes

Dace Grauda, Andra Mikelsone, Dalius Butkauskas,

Dāvis Rašals, Inese Vilcāne, Valters Gobinšš, Inga Lashenko

Protective properties of biotextile indicated by immature gamete

cells flow cytometry and Drosophila melanogaster survival tests

Ilze Dubova, Agnija Apine, Dace Grauda, Dalius Butkauskas, Inga Lashenko, Līga Jankevica

Adaptation of methods for the determination of biodegradation

of bio-textiles with amber particles

\section{Natalia Samokhvalova}

Genetic diversity of populations of the rare species Cypripedium

calceolus L. in Belarus

Tatsiana Shlapakova

Elemental composition of seeds of representatives of the genus

Turbinicarpus (Backeb.) Buxb. et Backeb. 


\title{
Protected water habitats in the landscape area "Augšdaugava"
}

\author{
Elmīra Boikova*1, Lelde Eṇğele ${ }^{2}$, Vita Līcīte', Uvis Suško ${ }^{1}$ \\ 1 Institute of Biology, University of Latvia, Jelgavas Street 1, Riga, Latvia, LV-1004 \\ 2 The Latvian Fund for Nature, Blauman, Street 32-8, Riga, Latvia, LV-1011 \\ * Corresponding author: Elmira.Boikova@lu.lv
}

\begin{abstract}
The "Augšdaugava" protected landscape area was established already in 1990, but the elaboration of the environment protection plan for this largest landscape area in Latvia is still in progress. The nature park "Daugavas loki" as part of this landscape area was established in 1990 and the nature park already has the protection and management plan (2010-2022). The upper Daugava river valley forms the central axis of the protected landscape area and is included in the Natura 2000 network. The complex of the Daugava River with nine large meanders and small, natural unaltered rivers, crossing the ravines, belongs to the Annex I habitat type 3260. This area is also rich in mineral springs and spring fens. There are about 30 lakes with different eutrophication impacts in the area. The possible threats, nature values, and water ecosystem services are discussed.
\end{abstract}

Keywords: The Daugava River, lakes and watercourses, NATURA 2000, ecosystem services

\section{The habitats of the Daugava River and its tributaries}

The flow of the Daugava River forms the main axis of the landscape protection area "Augšdaugava". Between the Latvian state border near Piedruja and Daugavpils city in $98 \mathrm{~km}$ length, the River Daugava and its valleys with unique nine meanders is an important river habitat complex. It consists of river sections with different flow rates, soils, plant and animal communities. The most typical river biotopes according to the European Union protected habitats classification in Latvia are:

- the river stretches with stony, shingly or gravelly river bed, with average flow velocity higher than $0.2 \mathrm{~m} / \mathrm{s}$ as well as natural unaltered river stretches regardless of flow velocity, identified as Annex I habitat type 3260,

- the muddy riverbanks with nitrogen loving pioneer vegetation - 3270,

- the riverbank with a stripe of vegetation (wet tall herb edge communities) 6430 . 
The Daugava's River dominant habitat is habitat type 3260 and therefore this unmodified ecosystem represents one of the most important and unique habitat types in Latvia and the European Union. Muddy riverbanks with nitrogen-loving annual pioneer vegetation form a specific habitat, the distribution of which is associated only with large rivers. The habitat is found only at low water levels, exposing the riverbed, where the vegetation characteristic of the habitat is forming. In the case of the Daugava River, this habitat was mapped in September 2011 along the banks and islands in 19 places with a total area of 20 ha. During the survey, the width of the exposed bed in the habitat was more than five meters and the characteristic species of this habitat were Chenopodium rubrum, Bidens cernus, B. tripartita, and Limosella aquatica.

River habitats are very important for many plant and animal species, they serve as a natural route for the migration of species, as well as ensure the existence of floodplain grasslands and forests dependent on the flood regime. Particularly valuable are river streams with rocky or pebbly soils, which are the only habitat for species that have adapted to life in fast-flowing, oxygen-rich waters. Oxygen-rich water in streams significantly accelerates the decomposition of organic matter and, consequently, the self-purification of water. In Latvia, it is a relatively rare habitat - only 17620 ha, which is $0.3 \%$ of the country (EU protected habitats in Latvia, interpretation manual, $2^{\text {nd }}$ revised edition, 2013).

The Daugava River water quality and hydrobiology were already well documented by scientists from the Institute of Biology (Кумсаре, 1967; Kumsare, 1972; Рудзрога, Друвиетис, 1984; www.kn.lv/raksti_data/422DAUGAVA, 2007) and the University of Daugavpils (Gruberts, 2006; Gruberts and Druvietis, 2006). By the Latvian Center for Environment, Geology, and Meteorology a monitoring assessment of the River Daugava has been carried out. In the last 20 years, an average of $64 \%$ of $N$ tot runoff and $92 \%$ of P tot runoff in the Daugava River loads are caused by the transboundary runoff (Belarus and Russia). In Latvia, the point sources are mainly responsible for loads to the Daugava River. Not only the increase of nutrient load - nitrogen and phosphorus at the border, but also the presence of toxic priority substances creates risks and threats to the quality of the Daugava River in the territory of Latvia. The environmental risk from waste disposal facilities in the Belarusian part of the Zapadnaja Dvina (Daugava) river basin is one of the threats as well (www.lvgmc. gov.lv). Recently, the quality indicators of the Daugava River are relatively good, however, they do not meet the quality requirements of the priority fish waters' quality.

Mapping of habitats of EU importance in the Daugava River itself and its tributaries was performed in 2017-2018 in the framework of the project Nature Census: https://www.skaitamdabu.gov.lv/public/eng. These results illustrate that Daugava river quality is on a medium/good level and this is in good agreement with National environment assessment data (2016-2019), based on EU Water framework directive EQ standards evaluation. 


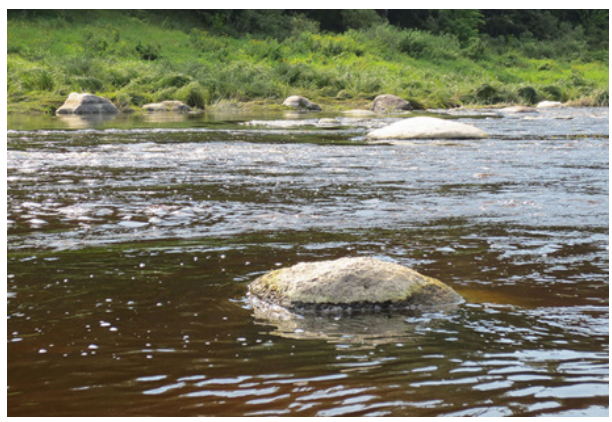

Figure 1. Daugava River by Indrica River, habitat 3260

(Photo: J. Smalinskis).

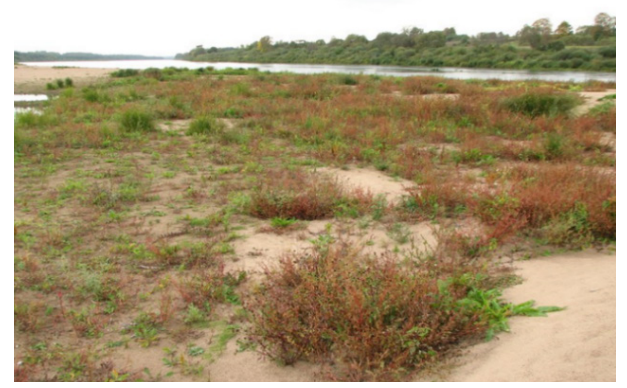

Figure 2. Daugava River near

the Dorbachova iland, habitat 3270 (Photo: A. Opmanis).

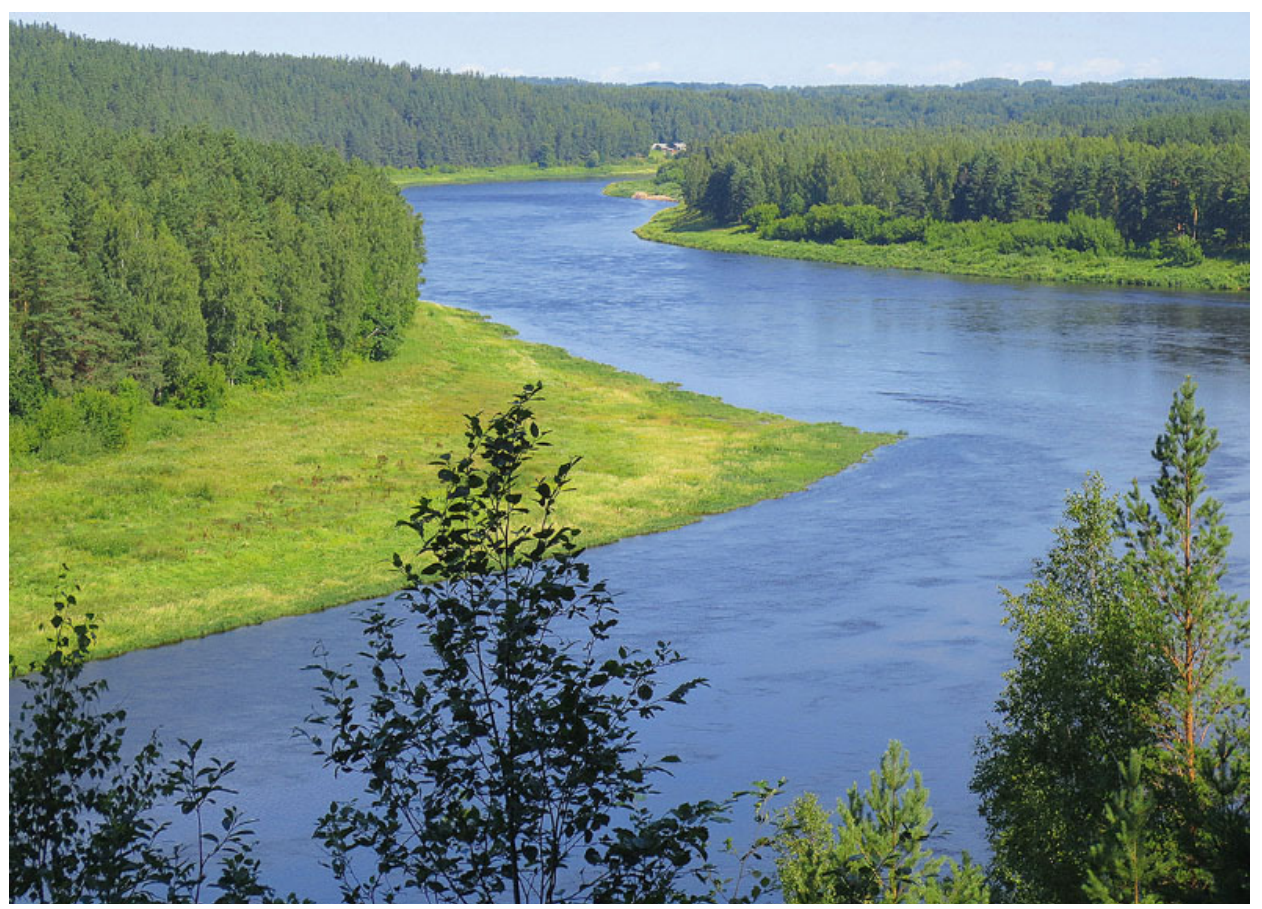

Figure 3. Daugava River meanders and valley from the Ververu Cliff (Photo: J. Smalinskis).

In the investigated area the Daugava River is rich in small tributaries which correspond to the Annex I habitat 3260. All these small rivers penetrate the Quaternary glacial sediments and wash out the fine-grained rubble. Their beds have a collection of boulders, pebbles, forming the steep rapids. There are also beautiful springs classified as the Annex I habitat 7160. 


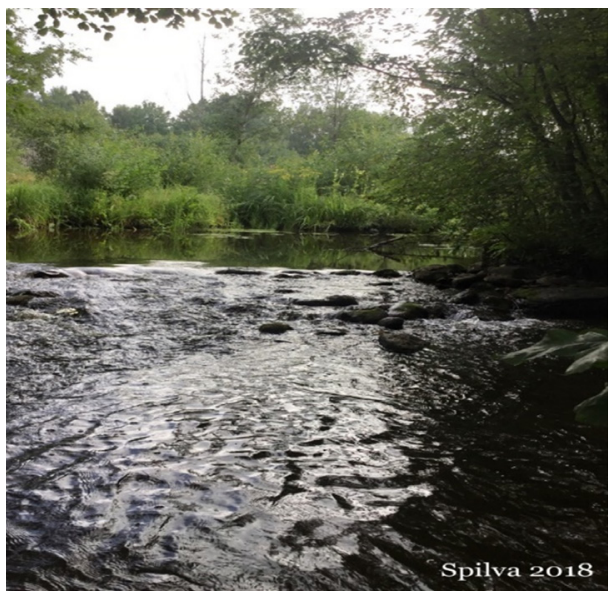

Figure 4. River Rudṇa, habitat 3260.

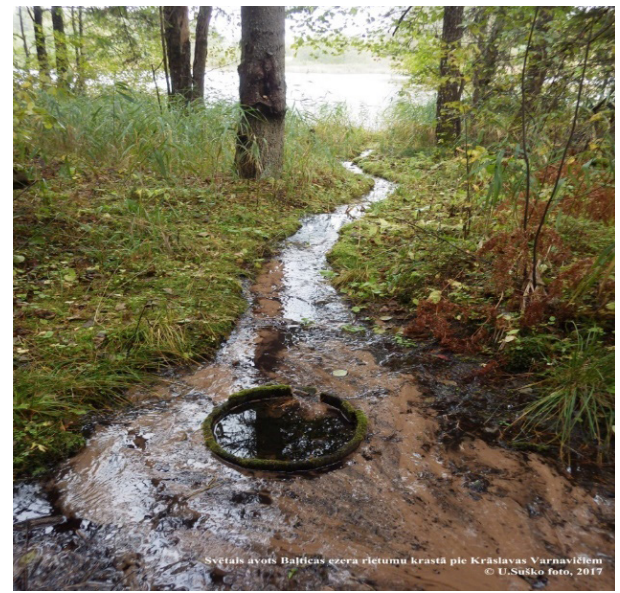

Figure 5. Spring near the lake, habitat 7160.

Small and rapid rivers are habitats for rheophilic species, including rare and threatened ones. The total overgrowth does not exceed $30 \%$ of optimal conditions, because a higher proportion decreases the flow velocity and favours the accumulation of nutrients. In several small rivers, beaver activity was detected as a threat to the rapid flow of a stream. In some places, shading is too intensive and sedimentation process from branches and leaves was observed.

\section{Protected landscape area lakes and their habitats}

If in the case of rivers their main function is the transportation of matter and energy flow, then for lakes this function is matter and energy accumulation. There are 31 lakes in the investigated area and all of them belong to the Daugava River catchment area. More detailed research of these lakes' quality and vegetation started only in 1990-ies (Suško, 1991, 1993, 1994, 1995, 1996; Suško and Bambe, 2002; Suško and Evarts-Bunders, 2010; Suško et al., 2018).

There is only one lake Varnaviči which corresponds to habitat 3130 of EU importance - Lakes with oligotrophic to mesotrophic plant communities. Lake Varnaviči is a very deep $(9 \mathrm{~m})$ mesotrophic lake of good quality, therefore maintaining, protecting, and improving its quality is a very important nature protection priority. This lake type is very rarely found in Latvia, it occupies in total 5570 ha or only $0.08 \%$ of the territory of the country.

All other 30 lakes belong to the habitat type 3150 - natural eutrophic lakes with Magnopotamium or Hydrocharition-type vegetation. These are lakes with the diverse and rich vegetation of submerged and floating plant species, with 
the water $\mathrm{pH}$ mostly exceeding value 7 . The habitat comprises clear water and brown water lakes with appropriate vegetation. The area occupied by this lake type is 66330 ha $-1 \%$ of the country. In Latvia the following habitat variants are distinguished:

- 3150_1: clear water lakes with submerged vegetation,

- 3150_2: brown-water lakes with diverse vegetation,

- 3150_3: oxbow lakes.

Fifteen lakes are classified as the first variant (3150_1), seven of them are of good quality, eight - of lowered water quality but 14 lakes - to the variant 3150_2 and only two of them are of good quality, others medium only.

In terms of nature values, the most important lakes are good quality eutrophic clearwater lakes, dyseutrophic brown-water lakes (mostly anthropogenically not affected, pollution-sensitive), and watershed lakes with small catchment areas and long water exchange period, and lakes located in forests.

Most of the studied lakes have a very significant landscape and aesthetic value. This is especially true for Lake Šilovka, which is surrounded by dry pine forests and is considered to be the largest and most beautiful lake in the protected landscape area.

Lakes have been affected by several factors related to human activities - landuse change, hydromelioration works and the resulting changes in the lake water level, arbitrary expansion of catchment areas as a result of excavation of natural watersheds, the inflow of nutrients from the agricultural lands in their catchment areas (arable land, pasture fertilization, farms, dairies, livestock swimming in lakes, mineral fertilizers, etc.), inhabited areas (incompletely treated or not drained), forests (clear-cutting, forest fertilization), as well as nutrient pollution of lakes caused by intensive recreation (bathing areas, saunas on the shores of lakes and guest houses). However, the lakes are also affected by their natural eutrophication processes.

In lakes, phosphorus $(\mathrm{P})$ is commonly the main nutrient limiting primary production. Therefore, controlling the human-induced external load of $\mathrm{P}$ to lakes is one of the main challenges in lake management. In Finland data were collected from 27 lakes and their trophic state varied from mesotrophic to hypereutrophic These lakes were chosen randomly among those where suitable data (P load measurements based on discharge and $\mathrm{P}$ concentration measurements and thus independent on land use information) were available. The results showed that catchment area to lake area ratio $(A \mathrm{C} / A \mathrm{~L})$, cultivated catchment area to lake area ratio $(A \mathrm{~F} / A \mathrm{~L})$, and percentage of cultivated land in the catchment $(F \%)$ can be used to predict the risk of exceeding the critical P load. However, $A F / A L$ had the best predicting power. This was because it contained information on both land use and catchment area variations (Horppila et al., 2019). Already according to previous investigations in watersheds with low transport. 


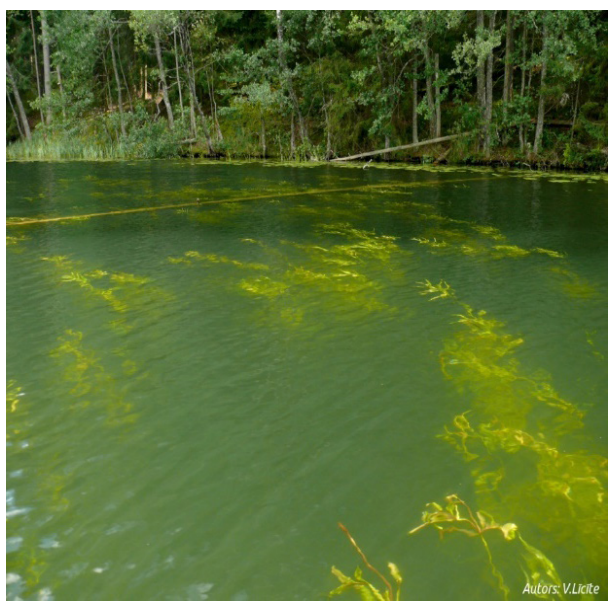

Figure 6. Lake Varnaviču, habitat 3130.

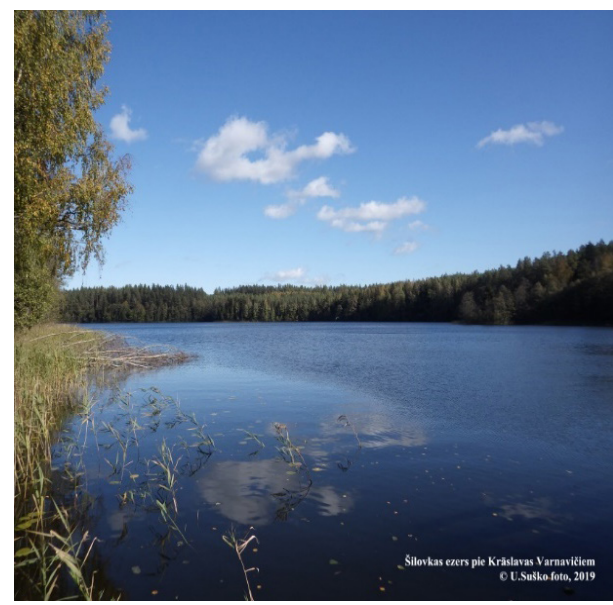

Figure 7. Lake Šilovka, habitat 3150.

Capacity, in-lake processes and near-shore land use/cover tended to be more influential, whereas, in watersheds with high transport capacity, land use/cover across the entire watershed was important for explaining lake chemistry. Thus, although land use is a key driver of nutrient loading to lakes, the extent to which it influences water quality can vary with watershed transport capacity (Fraterrigo and Downing, 2014). Forests clearcutting is one of the factors changing the nutrient flow to the lakes. Therefore during the development of the protection plan for the landscape area "Augšdaugava" for the first time according to expert V. Licite (2021) recommendation, we are proposing to restrict the clearcutting of forests in three lakes (Baltica, Šilovka, and Varnaviču) catchment areas to diminish the nutrient flow to the lakes.This could be a good management practice for the future to prevent the eutrophication processes of water ecosystems.

\section{Acknowledgements}

The Landscape area "Augšdaugava" protection and management plan for period 2022-2034 is financed by the project 'Preconditions for better biodiversity preservation and ecosystem protection in Latvia', or simply the 'Nature Census', and co-funded by the European Union Cohesion Fund: www.daba.gov.lv 


\section{References}

European Union Protected Habitats In Latvia. 2013. Interpretation manual $2^{\text {nd }}$ edition. Ed. A. Auniņš, p. 359.

Daugavas ekologiiskā stāvokḷa novērtējums. 2007. LU Bioloǵijas institūts, Salaspils. www.kn.lv/ raksti_data/422DAUGAVA, ATSKAITE.doc, 58. lpp.

Fraterrigo, J. M., Downing, J. A. 2014. The influence of land use on lake nutrients varies with watershed transport capacity. Ecosystems, $15 \mathrm{p}$.

Kumsare, A. 1972. Zur hydrobiologischen Rayonierung der Daugava. Verh. Internat. Verein. Limnol. 18: 751-755.

Gruberts, D. 2006. Palu pulsa koncepcija Daugavas vidusteces palien̦u ezeru ekologijā. Promocijas darbs. Daugavpils, 1.-152. lpp.

Gruberts, D., Druvietis, I. 2006. Impact of floods on composition, biomass, and diversity of phytoplankton communities of the Middle Daugava, in Latvia. In: Proceedings of $6^{\text {th }}$ International Symposium on Use of Algae for Monitoring Rivers. Ács, E., Kiss, K. T., Padisak, J., Szabo, K. E. (eds.). Hungary, Baltonfüred, 12-16 Sept. Pp. 54-59.

Horppila, J., Holmroos, H., Niemistö, J., and Tammeorg, O. 2019. Lake catchment characteristics and external P load-cultivated area/lake area ratio as a tool for evaluating the risk of eutrophication from land use information. Boreal Environment Research. 24: 13-23.

Kumsare, A. 1972. Zur hydrobiologischen Rayonierung der Daugava. Verh. Internat. Verein. Limnol. 18: 751-755.

Lìcīte, V. 2020. Sertificēta eksperta (sugu un biotopu aizsardzības jomā) atzinums par izpēti, stāvokḷa analīzi, aizsardzības un apsaimniekošanas pasākumu noteikšanu aizsargājamā ainavu apvidus “Augšdaugava” ezeros: Balticas ezers, Butišku ezers, Šilovkas ezers, Varnaviču ezers. 27.02.2020.

Nacionālais ziṇojums par vides stāvokli 2016-2019. www.meteo.lv

Suško, U. 1991. Mazā najāda Najas minor All. - jauna suga Latvijas florā. Retie augi. Rìga, 6.-9. lpp.

Suško, U. 1993. Varnaviču ezeraines morfometrija. DPU Dabas aizsardzības Inf. Biḷ. Daugavpils, 5, 14.-16. lpp.

Suško, U. 1994. Jaunas ziņas par Ilūkstes lielezeraines un citu Latvijas apgabalu reto un aizsargājamo augu atradnēm. Daba un Muzejs. Rīga, 5, 36.-42. lpp.

Suško, U. 1995. Ilūkstes lielezeraines glīvenes Potamogeton L. Maǵistra darbs biolog̣ijā. Daugavpils, 200 lpp.

Suško, U. 1997. Augšdaugavas dabisko ezeru botāniski-limnologisko pētījumu rezultāti Indricas un Varnaviču ezerainēs. Daba un Muzejs. Rīga, 7, 33.-39. lpp.

Suško, U., Bambe, B. 2002. Floristiskie pētījumi Augšzemes un Latgales ezeros. Retie augi. Rīga, 79.-94. lpp.

Suško, U., Evarts-Bunders, P. 2010. Botānisko pētījumu vēsture Dienvidaustrumlatvijā. Latvijas Veǵetācija. 21: 101-125.

Suško, U., Skrinda, I., Grīnberga, L., and Zviedre, E. 2018. Nozīmīgākie 2015.-2017. gada reto ùdensaugu atradumi Latvijas ezeros. Latvijas Universitätes 76. zinātniskā konference, Biologijas fakultātes Hidrobioloǵijas katedra, sekcijas "Latvijas ūdeñu vides pētījumi un aizsardzība" tēzes. 2018. gada 30. janvāris, 3. lpp.

Кумсаре, А. Я. 1967. Гидробиология реки Даугавы. Рига: Зинатне, с. 3-186.

Рудзрога, А. И., Друвиетис, И. Ю. 1984. Альгологические исследования реки Даугава. Санитарное состояние реки Даугавы. Даугавпилс, с. 24-29. 


\title{
Study of cloudberry Rubus chamaemorus L. genetic diversity in Latvia and Belarus based on different molecular marker systems
}

\author{
Nikole Krasṇevska*1, Dalius Butkauskas¹, Natalia Samokhvalova², \\ Andra Mikelsone ${ }^{1}$, Alesia Kruchonok², Dace Grauda1 \\ 1 Institute of Biology, University of Latvia, Jelgavas Street 1, Riga, Latvia, LV-1004 \\ 2 Central Botanical Garden of NAS of Belarus, Surganova Street 2 v, 220012, Minsk, Belarus \\ * Corresponding author: nikole.krasnevska@lu.lv
}

Keywords: Cloudberry, iPBS, retrotransposons, $5.8 \mathrm{~S}$ ribosomal DNA

Cloudberry (Rubus chamaemorus L.) is a perennial plant species from the genus Rosaceae with subarctic and boreal circumpolar distribution mainly in the Northern Hemisphere. In Europe, R. chamaemorus is widespread in Fennoscandia and Baltic countries (Thiem, 2003). In Central European countries $R$. chamaemorus occurs in small, isolated populations, and can be observed as a glacial relict (Ehrich et al., 2008). In Belarus, R. chamaemorus occurs only in the northern part of the country, and it is considered a critically endangered species with high protection level (Kachanovsky, 2015).

In this study, iPBS (inter-primer binding site) retrotransposon-based molecular markers marker system described by Kalendar et al. (2010) in combination with RChL-Ch1 and RChR-Ch1 primers designed for amplification and sequencing $5.8 \mathrm{~S}$ ribosomal RNA coding fragment was used to assess the genetic diversity and population genetic structure of Latvian and Belarus natural populations of $R$. chamaemorus. In total 276 samples from 12 populations, eight from Latvia and four from Belarus were analysed mainly by comparison iPBS polymorphism results.

Based on molecular data analysis genetic differentiation of cloudberry populations was evaluated by calculating the following parameters: percentage of polymorphic bands $(\mathrm{P})$, effective numbers of alleles $(\mathrm{Ne})$, the average number of $(\mathrm{Na})$, Shannon's Information Index (I), Nei's genetic diversity (He), total genetic diversity $(\mathrm{Ht})$, the mean within-population genetic diversity (Hs), genetic differentiation among different populations (Gst), and gene flow (Nm). 
Although the DNA sequencing of ITS 1, 5.8S ribosomal DNA fragment revealed the absence of point mutations among Latvian cloudberry samples some minor differences among Belarusian cloudberry populations were found.

From iPBS gained results we can conclude that despite low gene flow across studied samples, the genetic differentiation process among cloudberry populations from Belarus is more clearly expressed in comparison to Latvian populations.

\section{Acknowledgements}

The study was funded by the project "Evaluation of the cloudberry (Rubus chamaemorus L.) genetic resources of Latvia and Belarus as a background for the breeding program and conservation" (2019-2021) (project No. in Latvia LV-BY/2020/4, project No. in Belarus B19LATG004). The project is implemented as a part of a collaboration program in the field of science and technologies supported by the ministry of education and Science of the Republic of Latvia and the State Committee on Science and Technology of the Republic of Belarus.

\section{References}

Ehrich, D., Also, I. G., and Brochmann, C. 2008. Where did northern peatland species survive the dry glacials? Cloudberry (Rubus chamaemorus) as an example. Journal of Biogeography. 35: 801-814.

Kalendar, R., Antonius, K., Smykal, P., and Schulman, A. H. 2010. iPBS: a universal method for DNA fingerprinting and retrotransposon isolation. Theor. Appl. Genet. 121 (8): 1419-1430.

Kachanovsky, I. M. 2015. Red Book of the Republic of Belarus. Plants: rare and endangered species of wild plants. [Качановский И. М. [и др.]. Красная книга Республики Беларусь. Растения: редкие и находящиеся под угрозой исчезновения виды дикорастущих растения.] Belarusian Encyclopedia n/a Piatrus Browka. Minsk, 448 p. (in Russian).

Thiem, B. 2003. Rubus chamaemorus L. - a boreal plant rich in biologically active metabolites: a review. Biol. Lett. 40: 3-13. 


\title{
Trifolium repens L. genetic changes after UV-B radiation on the base of retrotransposon movement
}

\author{
Sandra Dombrovska, Dace Grauda*, Andra Miḳelsone \\ Institute of Biology, University of Latvia, Jelgavas Street 1, Riga, Latvia, LV-1004 \\ *Corresponding author: dace.grauda@lu.lv
}

\begin{abstract}
The white clover (Trifolium repens L.) has a wide distribution range of habitat - from the Arctic to the subtropics, as well as up to $6000 \mathrm{~m}$ high alpine regions. It is found in various areas - in the wild, in agricultural areas, and the urban environment. Retrotransposons are mobile genetic elements that can move through the genome using the "copy-paste" principle are activated when a plant is affected by a stressor. The ability to respond to environmental changes makes retrotransposons very successful functional markers for a stress study. A universal retrotransposon-based method iPBS (inter primer binding sites) which was developed by Kalendar et al. (2010) was used for the study of UV irradiation influence. It can be observed that after the treatment with UV-B radiation, the movement of retrotransposons is activated, which suggests that in this way protection against UV-B radiation is provided. It can be observed that the insertion of retrotransposons after irradiation with UV-B radiation within the same genotype takes place in the approximately same location in all the examined groups - after UV-B irradiation 15, 30, and 45 minutes.
\end{abstract}

Keywords: Trifolium repens, UV-B radiation, retrotransposons

\section{Introduction}

White (Dutch) clover Trifolium repens $\mathrm{L}$. is a cross-pollinated perennial herb that belongs to legume family (Leguminosae Juss.), typicum variety, both diploids $(2 \mathrm{n}=2 \mathrm{x}=16)$ and tetraploids plants $(2 \mathrm{n}=4 \mathrm{x}=32)$ are known (Voysey et al., 1994; Zhang et al., 2007; Jansone, 2008). T. repens grow worldwide and is one of the plant species cultivated in temperate climate zone in meadows, yards, gardens, along roads and streets, etc. (Roze, 2003; Roze, 2007; Ravagnani et al., 2012). It is also one of the components of grasslands. Since white clover is widespread in urban areas, including with various environmental pollution levels, it is the perfect plant species for adaptation studies. 
UV radiation ( $280-400 \mathrm{~nm}$ ), which reaches the Earth's surface, effectively regulates various physiological processes and metabolic pathways required for plant development. High absorption of UV radiation, especially UV-B $(280-316 \mathrm{~nm})$, can damage biological systems by degrading cellular DNA, reducing plant photosynthesis, chloroplast tilyloid integrity, and efficient biomass production. As a result of increased UV-B radiation intensity, reactive oxygen species as well as oxidative stress increase in plants. UV tolerance can vary significantly between species and varieties - some cultures may already be highly sensitive to current natural levels of UV-B radiation. Due to the great diversity of physiological and biochemical properties between species and varieties, as well as the increased plasticity and adaptive capacity observed under different growing conditions, it is worth studying the effects of UV-B radiation on populations from different environmental conditions, as climate change is predicted to have adverse effects on plant diversity (Caradus, 1994; Oliveira et al., 2019; Romero-Román et al., 2021).

This study is aimed to study the influence of UV irradiation on T. repens. A universal retrotransposon-based method iPBS (inter primer binding sites) which was developed by Kalendar et al. (2010) allows revealing a high level of genetic diversity and cost and labor are effective is cohoused for the study of UV irradiation influence. Retrotransposons are mobile genetic elements that can move through the genome using the "copy-paste" principle, thus multiplying themselves. Many studies show that retrotransposons are activated when a plant is affected by a stressor. The ability to respond to environmental changes makes retrotransposons successful functional markers responsible for adapting to changing environmental conditions (Bui and Grandbastien, 2012; Casacuberta and Gonzales, 2013).

\section{Material and methods}

\section{Plant material}

Four genotypes seeds of T. repens were used for the UV-B radiation experiment: Latvia origin variety "Daile", as well as genotypes from Gene Bank of the Slovak Republic from three different Tatra Mountains locations - Makov-Lovasovci (genotype 7), Oscadnica-Haladeji (genotype 9) and Oravsky Biely Potok (genotype 11). The experimental plants were grown in vitro under sterile conditions. The seeds were sterilized in three stages: 1) 10 minutes in soapy water, then rinsed with deionized water (at least 3 times); 2) 30 minutes in $0.7 \% \mathrm{KMnO} 4$ solution, then rinsed with deionized water; 3) 20 minutes in commercialized bleach solution ACE with a drop of Tween 80 , then rinsed with deionized autoclaved water in a laminar flow box. Sterile seeds were plated on Petri dishes on 6\% agar (pH 5.8) and placed in a $24{ }^{\circ} \mathrm{C}$ light thermostat with a photoperiod of $16 / 8$ hours day/night. After 21 days, the germinated plants were transplanted into cultivation boxes $(11 \times 9.5 \times 8 \mathrm{~cm})$ on 
L2 medium (Taylor and Quesenberry, 1996) and continued to grow in a thermostat under the same conditions.

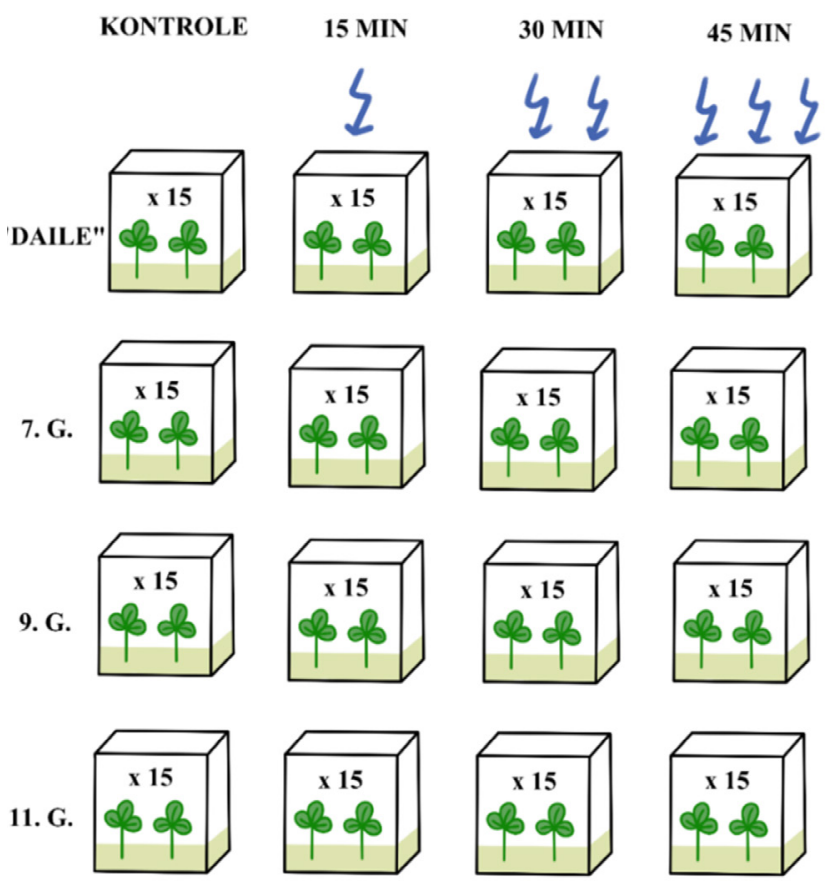

Figure 1. UV-B radiation experiment design ("Daile" - Latvian commercial variety "Daile"; 7. G. $-7^{\text {th }}$ genotype (Makov-Lovasovci); 9. G. $-9^{\text {th }}$ genotype (Oscadnica-Haladeji); 11 . G. $11^{\text {th }}$ genotype (Oravsky Biely Potok); KONTROLE - control group; 15 MIN - radiation with UV-B 15 minutes; 30 MIN - radiation with UV-B 30 minutes; 45 MIN - radiation with UV-B 45 minutes).

\section{UV-B irradiation experiment}

T. repens explants (leaves) taken from plants with at least four mature leaves were used for the UV-B irradiation experiment. 15 explants were planted on L2 medium in each in vitro cultivation box. Four experimental groups were set up: control and three with UV-B irradiation for 15, 30, and 45 minutes (Figure 1). The experiment was performed for seven days, irradiating at the same time each day.

\section{Molecular analysis}

After treatment of T. repens explants with UV-B radiation, DNA was isolated from all samples. DNA was isolated using CTAB DNA extraction protocol (Doyle and Doyle, 1987). 
PCR was performed on two primers, iPBS 2076 (5'-GCTCCGATGCCA-3') and iPBS 2079 (5'-AGGTGGCGCCA-3'). PCR for iPBS analysis was performed following Kalendar et al. (2010) protocol. PCR was performed in $0.2 \mathrm{~mL}$ tubes, the final volume of the reaction mixture was $25 \mu \mathrm{l}$, containing 1x DreamTaq PCR buffer, $1 \mathrm{mM}$ primer, $0.2 \mathrm{mM}$ each dNTP, $1.25 \mathrm{U}$ DreamTaq DNA polymerase, and 20-25 ng DNA. DNA amplification was performed in a GeneAmp PCRSystem 9700. PCR program included the following steps: initial denaturation at $95^{\circ} \mathrm{C}$ for 3 min, 30 cycles $\left(95^{\circ} \mathrm{C}\right.$ for $20 \mathrm{~s}, 50^{\circ} \mathrm{C}$ for $60 \mathrm{~s}, 68^{\circ} \mathrm{C}$ for $60 \mathrm{~s}$ ), and the final synthesis for $10 \mathrm{~min}$ at $72^{\circ} \mathrm{C}$.

PCR products were visualized using electrophoresis at $107 \mathrm{~V}$ for 7 hours on $1.7 \%$ agarose gel with $1 \mathrm{x}$ TAE electrophoresis buffer and were stained with ethidium bromide.

\section{Results and discussion}

Genotypes from Latvia and mountain areas were selected for this study based on the hypothesis that white clover in high-altitude areas could be better adapted to intense UV radiation and changes in their genome will be different from the genetic variability of Latvian samples. The movement of retrotransposons after irradiation with UV-B radiation could be observed in all examined genotypes using the iPBS 2079 primer. In the genotype "Daile" retrotransposon displacements were detected already after 15 minutes of irradiation (Figure 2). Changes in the genotype of T. repens 'Daile' can be observed in three loci, manifested as both: locus deletion and insertion. Locus deletion (sample 13) compared to the control group was observed after both 15 minutes and 30 minutes of irradiation, however, after 45 minutes of irradiation, the specific locus did not differ from the control group. Insertions are observed at two loci (sample 11). They are observed in all groups - after 15, 30, and 45 minutes of UV-B irradiation compared to the control group. For some individuals, exposure to UV-B radiation for 15 minutes a day during the week resulted in DNA degradation, so they were excluded from further analysis. In genotype 7, after 30 minutes of irradiation with UV-B radiation for the first sample, locus insertion can be found, but after 45 minutes of irradiation, the sample was degraded. In the second and sixth samples, locus deletion can be detected for 45 minutes after irradiation with UV-B radiation.

The majority (nine out of fifteen) of genotype individuals were degraded. After 15 minutes of irradiation with UV-B radiation, deletion of the locus can be observed in the first sample, however, 30 minutes after irradiation, the locus does not differ from the control group. The same sample DNA after 45 minutes with UV-B radiation was degraded. Irradiation for 45 minutes with UV-B radiation is too intense for this genotype, so degradation of most samples is observed. 

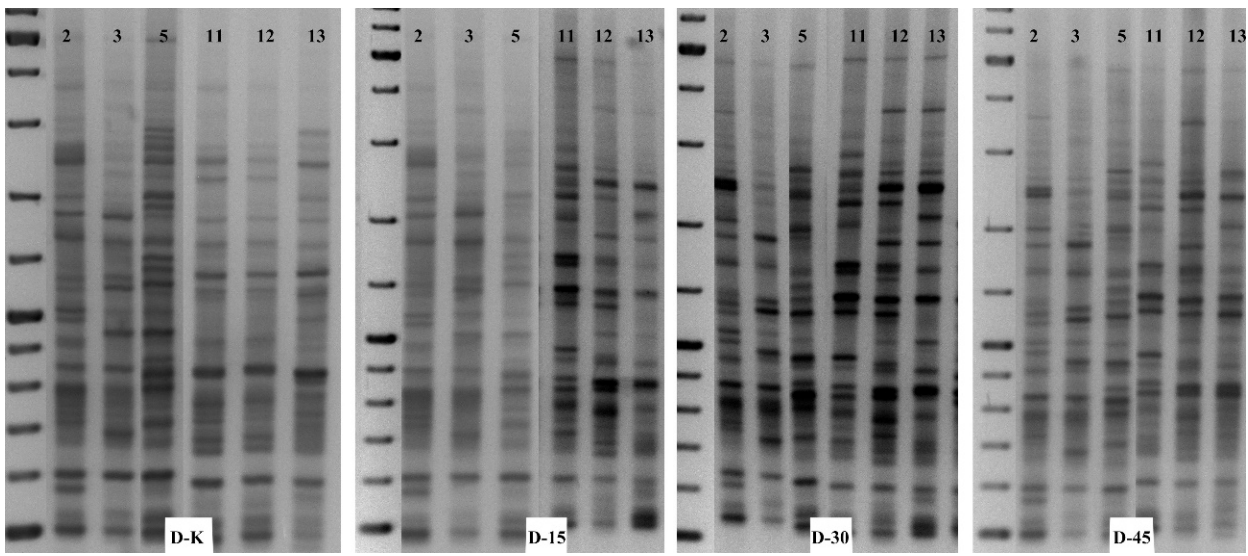

Figure 2. Movement of retrotransposons in the "Daile" genotype using the iPBS 2079 primer (D-K - control; D-15 - irradiation with UV-B radiation for 15 minutes; D-30 irradiation with UV-B radiation for 30 minutes; D-45 - irradiation with UV- B radiation for 45 minutes).

For genotype 11 samples after 15 minutes of UV-B irradiation, all samples DNA were degraded and these samples were removed from further analysis. In the fifth locus, 30 minutes after irradiation, locus insertion can be observed, which can also be observed after 45 minutes of irradiation, but in the sixth and seventh samples, locus deletion can be observed after both 30 and 45 minutes of UV-B irradiation.

Based on the features of the length marker in both genotype 11 and Daile retrotransposons, displacements have been detected around the same DNA region.

Genetic diversity is essential for any species to be able to adapt to and survive changing environmental conditions. This is particularly important because the climate on our planet is currently deteriorating due to human activity. To improve the quality of food and the environment, it is necessary to preserve and stabilize the genetic diversity of species. There is a need not only to improve the genetic diversity of crops but also to pay attention to their wild ancestors. Plant genetic resources are the basis for ecological and high-quality environmental development, ensuring the conservation of food and other biological resources. As a result of anthropogenic influences, natural ecosystems are fragmented, leading to a decline in genetic diversity, as the natural distribution of many species is limited (Maxted et al., 2008). Small, isolated populations are potentially at risk of inbreeding, loss of genetic diversity and are at risk of genetic erosion. Genetic diversity helps the species to evolve and to protect itself from inbreeding, which has a negative effect, as the possibility of this can increase the number of harmful recessive alleles in natural cross-pollinated populations. Studies show that increased genetic erosion 
affects $20-35 \%$ of plant species diversity. Crops account for only about $3 \%$ of all plant species. Plant genetic diversity increases choice and protection against future adverse environmental conditions (Bome et al., 2015; Frankham et al., 2017).

According to the results, it can be observed that after the treatment with UV-B radiation, the movement of retrotransposons is activated, which suggests that in this way protection against UV-B radiation is provided. It can be observed that the insertion of retrotransposons after irradiation with UV-B radiation within the same genotype takes place in the approximately same location in all the examined groups - after UV-B irradiation 15, 30, and 45 minutes, however, the literature reports, that retrotransposon insertion occurs randomly (Masuta et al., 2017), usually in non-chromatic regions. Based on the features of the length marker in two genotypes ( $11^{\text {th }}$ and "Daile"), retrotransposon displacements were detected around the same DNA region. The results could be extended by sequencing specific loci, as well as studying the gene functions of specific insertion sites using information available in databases.

\section{Acknowledgments}

This work was performed in the implementation of LU project Y5-AZ81ZF-N-805 "Living organisms research in towns, country, and water ecosystems".

\section{References}

Bome, N. A., Bome, A. Y., and Ripberger, E. I. 2015. Ecological and genetic potential of sort spring wheat in conditions of the northern zauralye. In: Biological Systems, Biodiversity, and Stability of Plant Communities. Eds. Weisfeld, Opalko, Bome, and Bekuzarova. 527 p.

Bui, Q. T., Grandbastien, M. A. 2012. LTR Retrotransposons as Controlling Elements of Genome Response to Stress? In: Plant Transposable Elements: Impact on Genome Structure and Function Topics in Current Genetics. Eds. Grandbastien and Casacuberta. Pp. 273-296.

Caradus, J. R. 1994. Genetic diversity within white clover (Trifolium repens L.). Proceedings Agronomy Society of N. Z. 24: 1-7.

Casacuberta, E., Gonzalez, J. 2013. The impact of transposable elements in environmental adaptation. Molecular Ecology. 22: 1503-1517.

Doyle, J. J., Doyle, J. L. 1987. A rapid DNA isolation procedure from small quantities of fresh leaf tissues. Phytochem Bull. 19(1): 11-15.

Frankham, R., Ballou, J. D., Ralls, K., Eldridge, M. D. B., Dudash, M. R., Fenster, C. B., Lacy, R. C., and Sunnucks, P. 2017. Genetic Management of Fragmented Animal and Plant Populations. Oxford University Press, 401. p.

Jansone, B. 2008. Baltais āboliņš (White clover). In: Celvedis daudzgadīgo zālaugu sēklaudzēšanā (Guide Book in the Seed Production of Forage Grasses). Eds. Jansone, Rancāne, Dzenis, and Jansons. Pp. 78-87 (in Latvian). 
Kalendar, R., Antonius, K., Smykal, P., and Schulman, A. H. 2010. iPBS: a universal method for DNA fingerprinting and retrotransposon isolation. Theor. Appl. Genet. 121: 1419-1430.

Masuta, Y., Nozawa, K., Takagi, H., Yaegashi, H., Tanaka, K., Ito, T., Saito, H., Kobayashi, H., Matsunaga, W., Masuda, S., Kato, A., and Ito, H. 2017. Inducible Transposition of a HeatActivated Retrotransposon in Tissue Culture. Plant Cell Physiol. 58(2): 375-384.

Maxted, N., Iriondo, J. M., Dulloo, M. E., and Lane, A. 2008. Introduction: The Integration of PGR Conservation with Protected Area Management. In: Conserving Plant Genetic Diversity in Protected Areas. Eds. Iriondo, Maxted, and Dulloo. Pp. 1-22.

Oliveira, A. F., Rais, F., Dettori, I., Azzena, M., and Nieddu, G. 2019. UV Light Acclimation Capacity of Leaf Photosynthetic and Photochemical Behaviour in Near-isohydric and Anisohydric Grapevines in Hot and Dry Environments. S. Afr. J. Enol. Vitic. 40(2): 188-205.

Ravagnani, A., Abberton Michael, T. and Skøt, L. 2012. Development of Genomic Resources in the Species of Trifolium L. and Its Application in Forage Legume Breeding. Agronomy. 2(2): $116-131$.

Romero-Román, M. E., Schoebitz, M., Bastías, R. M., Fernández, P. S., García-Viguera, C., and López-Belchi, M. D. 2021. Native Species Facing Climate Changes: Response of Calafate Berries to Low Temperature and UV Radiation. Foods. 10: 196.

Roze, I. 2003. Genus Trifolium L. in the flora of Latvia. Acta Biologica Universitatis Daugavpiliensis. 3(1): 33-40.

Roze, I. 2007. Āboliṇa Trifolium L. gints Latvijas florā (Clover Trifolium L. in the flora of Latvia). Latvijas Veǵetācija. 13: 17-32 (in Latvian, with English summary).

Taylor, N. L., Quesenberry, K. H. 1996. Red Clover Science. Eds. Summerfield. P. 228.

Voysey, C. R., White, D., Dudas, W. R., and Ealing, R. D. 1994. Agrobacterium mediated transformation of white clover. Plant Cell. 13: 309-314.

Zhang, Y., Sledge, M. K., and Bouton, J. H. 2007. Genome mapping of white clover (Trifolium repens L.) and comparative analysis within the Trifolieae using cross-species SSR markers. Theor Appl Genet. 114: 1367-1378. 


\section{Bacterial cellulose production on whey - an overview of prospects}

\section{Sergejs Koḷesovs, Kristaps Neiberts, Maija Rukliša, Pāvels Semjonovs*}

Institute of Biology, University of Latvia, Ojāra Vācieša street 4, Riga, Latvia, LV-1004

*Corresponding author: psem@latnet.lv

Keywords: whey, bacterial cellulose, acetic acid bacteria, whey valorisation

Bacterial cellulose (BC) is a biopolymer with a wide range of potential applications starting from the food and packaging industry to biomedicine and electronics. Despite its high potential, BC large-scale production remains still challenging (Jozala et al., 2015; Azeredo et al., 2019). The high cost of growth media, which can reach up to $30 \%$ of production costs is one of them. To decrease production costs, the use of industrial and agricultural by-products (Table 2), including whey (Table 1 and 2), as alternative growth media can be considered. Whey is the main high-volume by-product of the dairy industry and can be considered as an alternative growth medium for BC production despite its low valorisation opportunities. Only a few research articles are dedicated to the evaluation of BC productivity on whey media. BC production on whey medium is highly strain-specific and is associated with strains' ability to hydrolyse lactose which is the main C source in whey (Semjonovs et al., 2017; Revin et al., 2018). Several strains do not support BC synthesis on whey or lactose-containing media (Thompson and Hamilton, 2001).

Our study shows that Komagataeibacter rhaeticus P-1463 can produce up to $1.95 \pm 0.15 \mathrm{~g} / \mathrm{L}$ of BC (dry weight) during 10 days of cultivation on the unhydrolyzed whey medium, thus assimilating lactose and relevant monosaccharides as $\mathrm{C}$ substrate. Moreover, K. rhaeticus $\mathrm{P}-1463$ utilises galactose and lactose in a modified HS medium (Table 1). Whey enzymatic pretreatment with $\beta$-galactosidase increased BC production by K. rhaeticus P-1463 to $2.41 \mathrm{~g} / \mathrm{L}$ (dry weight). Probably there are limiting factors besides $\mathrm{C}$ and $\mathrm{N}$ concentrations restricting $\mathrm{BC}$ production in whey medium. 
Table 1. BC production on standard and modified HS media (K. rhaeticus P-1463)

\begin{tabular}{|l|c|c|}
\hline \multicolumn{1}{|c|}{ Medium } & BC dry weight, g/L & Productivity QX, g/L/d \\
\hline HS medium & $3.68 \pm 0.03$ & 0.37 \\
\hline Modified HS medium with lactose & $2.85 \pm 0.04$ & 0.29 \\
\hline Modified HS medium with galactose & $2.1 \pm 0.02$ & 0.21 \\
\hline Whey & $1.95 \pm 0.15 \mathrm{~g} / \mathrm{L}$ & 0.19 \\
\hline
\end{tabular}

Table 2. Comparison of $B C$ production on whey with other alternative substrates.

Table adapted from (Kolesovs and Semjonovs, 2020)

\begin{tabular}{|c|c|c|c|}
\hline Mudium & Strain & BC dry weight, $g / L$ & Reference \\
\hline $\begin{array}{l}\text { Whey medium (no } \\
\text { pre-treatment) }\end{array}$ & K. rhaeticus P-1463 & 1.95 & Current research \\
\hline $\begin{array}{l}\text { Hydrolised whey } \\
\text { ( } \beta \text {-galactosidase } \\
\text { pre-treated) }\end{array}$ & K. rhaeticus P-1463 & 2.41 & Current research \\
\hline Whey & $\begin{array}{c}\text { G. sucrofermentans } \\
\text { B- } 11267\end{array}$ & 5.45 & (Revin et al., 2018) \\
\hline Whey & K. xylinus DSM 2325 & 6.77 & (Rollini et al., 2020) \\
\hline Corn steep liqour & $\begin{array}{c}\text { A. xylinum NRRL } \\
\text { B-42 }\end{array}$ & 6.7 & $\begin{array}{c}\text { (Cerrutti et al., } \\
\text { 2016) }\end{array}$ \\
\hline Orange juice & $\begin{array}{c}\text { A. xylinum NBRC } \\
13693\end{array}$ & 5.9 & $\begin{array}{c}\text { (Kurosumi et al., } \\
\text { 2009) }\end{array}$ \\
\hline Apple juice & $\begin{array}{c}\text { A. xylinum NBRC } \\
13693\end{array}$ & 3.9 & $\begin{array}{c}\text { (Kurosumi et al., } \\
\text { 2009) }\end{array}$ \\
\hline Pineaple juice & $\begin{array}{c}\text { A. xylinum NBRC } \\
13693\end{array}$ & 3.9 & $\begin{array}{c}\text { (Kurosumi et al., } \\
\text { 2009) }\end{array}$ \\
\hline Molases & A. xylinum BPR2001 & 5.3 & $\begin{array}{c}\text { (Bae and Shoda, } \\
\text { 2004) }\end{array}$ \\
\hline Glycerol & $\begin{array}{c}\text { G. xylinus CGMCC } \\
\text { no. } 2955\end{array}$ & 5.97 & (Zhong et al., 2013) \\
\hline $\begin{array}{l}\text { Wheat enzymatic } \\
\text { hydrolysate }\end{array}$ & $\begin{array}{c}\text { A. xylinus ATCC } \\
23770\end{array}$ & 8.3 & (Chen et al., 2013) \\
\hline $\begin{array}{l}\text { Coconut water (Nata } \\
\text { de Coco) }\end{array}$ & Acetic acid bacteria & 712.9 (wet weight) & (Phong et al., 2017) \\
\hline
\end{tabular}




\section{Conclusions}

Currently whey can be recognised as challenging and still quite a problematic alternative growth substrate for large-scale $\mathrm{BC}$ production. It was shown that whey is a suitable and promising medium for $\mathrm{BC}$ synthesis by acetic acid bacteria strain $K$. rhaeticus $\mathrm{P}-1463$. At the same time, the use of untreated whey results in significantly lower BC if compared to standard HS medium. Further extensive studies may improve the prospects in both - the search for cheap alternative growth substrates for industrial BC production and valorisation of whey.

\section{Acknowledgments}

Project No. 19-00-A01612-000004 "Obtaining of bio-degradable polymers from renewable resources for the production of protective coatings and packaging materials for fruits" is co-financed by the European agricultural fund for rural development (EAFRD). This study was supported by the Ministry of Agriculture and Rural Support Service of the Republic of Latvia.

\section{References}

Azeredo, H. M. C., Barud, H., Farinas, C. S., Vasconcellos, V. M., and Claro, A. M. 2019. Bacterial Cellulose as a Raw Material for Food and Food Packaging Applications. Front Sustain Food Syst 3. https://doi.org/10.3389/fsufs.2019.00007

Bae, S., Shoda, M. 2004. Bacterial cellulose production by fed-batch fermentation in molasses medium. Biotechnol Prog. 20: 1366-1371. https://doi.org/10.1021/bp0498490

Cerrutti, P., Roldán, P., García, R. M., Galvagno, M. A., Vázquez, A., and Foresti, M. L. 2016. Production of bacterial nanocellulose from wine industry residues: Importance of fermentation time on pellicle characteristics. J Appl Polym Sci. 133: 1-9. https://doi.org/10.1002/app.43109

Chen, L., Hong, F., Yang, X.-xia, and Han, S.-fen 2013. Biotransformation of wheat straw to bacterial cellulose and its mechanism. Bioresour Technol. 135: 464-468. https://doi.org/10.1016/j. biortech.2012.10.029

Jozala, A. F., Pértile, R. A. N., dos Santos, C. A., de Carvalho Santos-Ebinuma, V., Seckler, M. M., Gama, F. M., and Pessoa, A. 2015. Bacterial cellulose production by Gluconacetobacter xylinus by employing alternative culture media. Appl Microbiol Biotechnol. 99: 1181-1190. https://doi.org/ $10.1007 /$ s00253-014-6232-3

Kolesovs, S., Semjonovs, P. 2020. Production of bacterial cellulose from whey -current state and prospects. Appl Microbiol Biotechnol. 104: 7723-7730. https://doi.org/10.1007/s00253-02010803-9

Kurosumi, A., Sasaki, C., Yamashita, Y., and Nakamura, Y. 2009. Utilization of various fruit juices as carbon source for production of bacterial cellulose by Acetobacter xylinum NBRC 13693. Carbohydr Polym. 76: 333-335. https://doi.org/10.1016/j.carbpol.2008.11.009 
Phong, H. X., Lin, L. T., Thanh, N. N., Long, B. H., and Dung, N. T. P. 2017. Investigating the conditions for nata-de-coco production by newly isolated Acetobacter sp. Am J Food Sci Nutr. 4: 1-6.

Revin, V., Liyaskina, E., Nazarkina, M., Bogatyreva, A., and Shchankin, M. 2018. Cost-effective production of bacterial cellulose using acidic food industry by-products. Brazilian J Microbiol. 49: 151-159. https://doi.org/10.1016/j.bjm.2017.12.012

Rollini, M., Musatti, A., Cavicchioli, D., Bussini, D., Farris, S., Rovera, C., Romano, D., De Benedetti, S., and Barbiroli, A. 2020. From cheese whey permeate to Sakacin-A/bacterial cellulose nanocrystal conjugates for antimicrobial food packaging applications: a circular economy case study. Sci Rep. 10: 1-14. https://doi.org/10.1038/s41598-020-78430-y

Semjonovs, P., Ruklisha, M., Paegle, L., Saka, M., Treimane, R., Skute, M., Rozenberga, L., Vikele, L., Sabovics, M., and Cleenwerck, I. 2017. Cellulose synthesis by Komagataeibacter rhaeticus strain P 1463 isolated from Kombucha. Appl Microbiol Biotechnol. 101(3): 1003-1012.

Thompson, D. N., Hamilton, M. A. 2001. Production of bacterial cellulose from alternate feedstocks. Appl Biochem Biotechnol - Part A Enzym Eng Biotechnol. 91-93: 503-513. https://doi.org/10.1385/ ABAB:91-93:1-9:503

Zhong, C., Zhang, G. C., Liu, M., Zheng, X. T., Han, P. P., and Jia, S. R. 2013. Metabolic flux analysis of Gluconacetobacter xylinus for bacterial cellulose production. Appl Microbiol Biotechnol. 97: 6189-6199. https://doi.org/10.1007/s00253-013-4908-8 


\title{
Experimental evidence of the impact of low-frequency electromagnetic field on the reproductive success of fruit fly Drosopfila melanogaster and its potential to generate new point mutations at some candidate genes
}

\author{
Dalius Butkauskas*1, 2, Dace Grauda², Andra Miḳelsone², Dāvis Rašals², \\ Rimantas Petrošius ${ }^{1}$, Kamilè Kazlauskaitė ${ }^{1}$ \\ 1 Nature Research Centre, Akademijos Street 2, LT-08412, Vilnius, Lithuania \\ 2 Institute of Biology, University of Latvia, Jelgavas Street 1, Riga, Latvia, LV-1004 \\ * Corresponding author: dalius.butkauskas@lu.lv
}

Keywords: Drosophila melanogaster, LF electromagnetic field, reproductive success, Isocitrate dehydrogenase as a candidate locus

The effects of microwave frequency electromagnetic fields on the development of Drosophila melanogaster were already demonstrated (Atli and Ünlü, 2006). To collect data as new evidence regarding the impact of low frequency $(50 \mathrm{~Hz})$ electromagnetic field (LFEF) on fruitflies up to five generations of D. melanogaster of the Oregon line were exposed to LFEF by growing insects in plastic tubes placed inside Helmholc coil, producing a region of nearly uniform magnetic field (500$750 \mu \mathrm{T})$. All fruit flies were placed on a standard sugar-yeast-cornmeal medium at $24 \pm 2{ }^{\circ} \mathrm{C}$ temperature. Initially, 50 larvaes were placed in each tube (10 tubes placed inside the coil represent directly affected group EM*, the next 10 tubes marked as control group $\mathrm{K}^{\star}$ were placed in 1.5 meters distance from the coil). To establish the next generation of $\mathrm{K}^{\star}$ and $\mathrm{EM}^{\star}$ groups two fertilised females were replanted from each of 10 tubes and placed in the same number of tubes to continue the collection of the data including fixation of the number of dead pupas and insects that reached imago stage. The experiment has been terminated after the fifth generation of fruit flies developed up to imago stage.

No alive flies of the fifth generation were obtained in one out of ten tubes at the control group and just a few flies of the fifth generation were found in four out of ten tubes in $\mathrm{EM}^{\star}$ group. In the rest six tubes, no alive flies were found in 
the directly exposed to LFEF group, revealing the negative impact of electromagnetic field on reproductive success based on the current experimental model.

Taking into account the results of the study that revealed the role of the Isocitrate dehydrogenase in the protection of DJ-1 null dopaminergic cells from oxidative stress (Yang et al., 2017; Kocaman et al., 2018) we sequenced potentially variable part of Isocitrate dehydrogenase as candidate locus to detect LFEF born mutagenesis. No poin mutations of Isocitrate dehidrogenaze (Idh) $1218 \mathrm{bp}$ fragment were found based on sequencing and alignment of DNA comparing representatives of $\mathrm{EM}^{\star}$ and $\mathrm{K}^{\star}$ groups.

The study should be extended including experiments devoted to the selection of the most informative and sensitive loci in combination with evaluation of the impact of electromagnetic fields of different intensity and frequency.

\section{Acknowledgements}

The study was financially supported by the EURECA project E!11170 "Innovative multifunctional bio-textile, integrated with silica dioxide and succinate development, and its impact on biosystems" IFSITEX.

\section{References}

Atli, E., Ünlü, H. 2006. The effects of microwave frequency electromagnetic fields on the development of Drosophila melanogaster. International Journal of Radiation Biology. 82: 435-441.

Kocaman, A., Altun, G., Kaplan, A. A., Deniz, Ö. G., Yurt, K. K., and Kaplan, S. 2018. Genotoxic and carcinogenic effects of non-ionizing electromagnetic fields. Environmental Research. 163: 71-79.

Yang, J., Kim, M. J., Yoon, W., Kim, E. Y., Kim, H., Lee, Y., Min, B., Kang, K. S., Son, J. H., Park, H. T., Chung, J., and Koh, H. 2017. Isocitrate protects DJ-1 null dopaminergic cells from oxidative stress through NADP+-dependent isocitrate dehydrogenase (IDH). PLoS Genet. 13, e1006975. 


\title{
Protective properties of biotextile indicated by immature gamete cells flow cytometry and Drosophila melanogaster survival tests
}

\section{Dace Grauda*1, Andra Miḳelsone1, Dalius Butkauskas', 2, Dāvis Rašals, Inese Vilcāne ${ }^{1}$, Valters Gobiņšs ${ }^{1}$, Inga Lashenko3,4}

1 Institute of Biology, University of Latvia, Jelgavas Street 1, Riga, Latvia, LV-1004

2 Nature Research Centre, Akademijos Street 2, LT-08412, Vilnius, Lithuania

3 SIA “ILU Technologies”, Skārn,u Street, Riga, Latvia, LV-1050

4 Riga Technical University, Institute of Mechanics and Mechanical Engineering, Mechanics and Biotextile Research Laboratory, Kīpsalas iela 6B-406, Riga, Latvia, LV-1048

*Corresponding author: dace.grauda@lu.lv

\begin{abstract}
The testing of an innovative amber-containing biotextile developed within the EUREKA project IFSITEX revealed the ability of biotextile material to protect test objects from UV-B radiation and extremely low-frequency electromagnetic fields (ELF-EMFs). One of two different testing methods is based on flow cytometry indicating changes in the relative fluorescence of immature plant gametes based on the determination of the sum of changes in approximately 20 various parameters of gametic cells affected in one nuclear stage by irradiation of cell suspension covered with biotextile fabrics containing amber particles or similar fabrics lacking amber particles with UV-B for 75 minutes. The second test called Drosophila melanogaster survivability test, specifically modified for biotextile testing, revealed differences in the percentage of successful development of $D$. melanogaster from larvae to imago stage after growing fruit flies in tubes covered with biotextile material containing amber particles as well as material free of amber particles. Tubes with $D$. melanogaster larvae were placed in a Helmholtz coil were continuously exposed to a sinusoidal $50 \mathrm{~Hz}$ magnetic field (MF) at a flux of $450 \mu \mathrm{T}$. Survivability results were compared to the success of the development of the control which was not affected by experimentally generated ELF-EMFs $D$. melanogaster. Samples of biotextile containing amber particles were found to retain UV-B and LF-EMF radiation better than fabric samples without amber particles.
\end{abstract}

Keywords: Biotextile protection properties, UV-B, ELF-EMF, amber, immature gametic cells, Drosophila melanogaster 


\section{Introduction}

This paper reports the results from biotesting of biotextile's protective properties for shielding test objects from the impact of electromagnetic fields (EMF) and UV-B of different wavelengths. Test methods were selected and implemented so that they could be used to test the protective properties of new materials. During the development of new biotextile materials, close cooperation between textile engineers and biological testers has become commonplace, focusing on fast feedback as the results of bio-testing may significantly accelerate the development of new high-quality materials. Prior studies carried out at the University of Latvia (UL) and JLU Technologies Ltd showed that succinite possesses specific properties, i.e., the ability to increase parameters of cell activity, and it was emphasized that its influence on tested cells was harmless (Lyashenko, 2014; Grauda et al., 2015). It is known that amber (succinite) has characteristics (magnetic properties, ability to lose electrons as a result of impact of UV radiation, and content of polyether compounds) that potentially could decrease the influence of environmental factors such as increased UV-B radiation and experimentally low-frequency electromagnetic fields (ELF-EMFs). Thus, the current research was carried out to find the optimal concentration, as well as other parameters, of succinite particles used for the manufacturing of biotextile materials that would meet optimal mechanical and biological requirements. To determine the multivariate effects of newly developed biotextile materials on eukaryotic cells and model organisms, we choose to adapt relatively fast and reliable methods for applications in new areas like biotextile biotesting.

A complex approach to biotextile development led to positive changes in the development of new biotexstile materials: the development of laboratory tests used to determine biological activity of biotextiles and raw materials based on complex, systemic, and sustainable studies will have an essential impact on biotesting, making it more justified, comparable, repeatable, at the same time reducing costs.

\section{Materials and Methods}

The potential to use in vitro culture of gametic cells arranged for cultivation as described earlier (Barnabás, 2003; Kasha et al., 2003) was first demonstrated by our research group developing methods to study biotextile protective properties against UV-B and ELF-EMF ( $50 \mathrm{~Hz}$ magnetic field, $450 \mu \mathrm{T}$ ) radiation (Figure 1). We chose to study 8 considerable repeats using cyclamen (Cyclamen persicum) cells to perform testing based on flow cytometry (FCM) as one of the most rapid evaluations of changes of cell parameters after UV-B irradiation and for ELF-EMFs impact assessment. 
BD FACSJazz ${ }^{\circledast}$ cell sorter (BD Biosciences, USA) was used to test the relative fluorescence (RF) of cells. According to earlier tests performed using the blue laser (488 nm) (Grauda et al., 2015) new, original biotextile properties testing method was developed (the method is in the process of patenting). Statistical calculations were made using MS Excel software. The $p$-value threshold $(P<0.05)$ was used in evaluations of statistical significance.

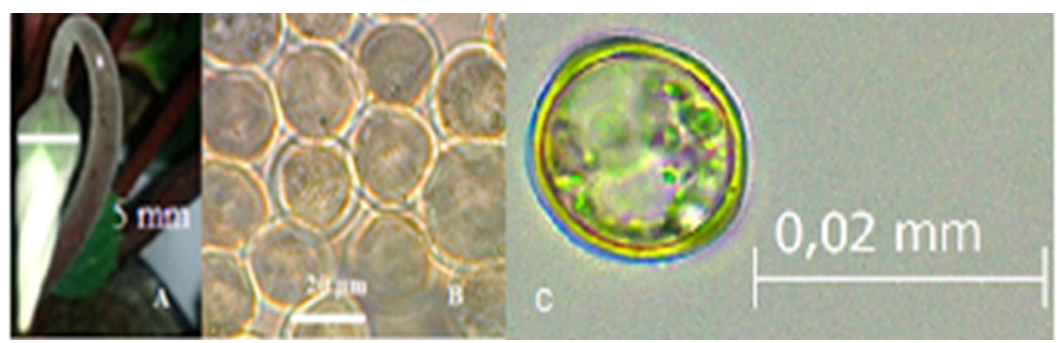

Figure 1. The buds of $C$. persicum (A) contain more than $80 \%$ gametic cells (microspores) in early and middle uninucleate developmental stage (B), Isolated gametic cell in the middle uninucleate developmental stage (C).

To determine the protective performance of different biotextile fabrics UV-B lamp was placed $30 \mathrm{~cm}$ above the table's surface (at $365 \mathrm{~nm}$ intensity). The Petri plates with the suspension of gametic cells were irradiated with UV-B keeping them in closed Petri dishes covered with different textile specimens made with incorporated and without incorporated amber yarn. Besides tested fabrics, a positive control (uncovered Petri dish) was used. The exposure to UV-B irradiation was continued for 70 minutes.

For determination of the anti- ELF-EMFs resistance of the newly formed textile materials, a Helmholtz coil was used (Figure 2). Specifically, the Helmholtz coil forms a constant magnetic field, $50 \mathrm{~Hz}$ inside of the device. The advantage of the Helmholtz coil for conducting experiments is that it produces a uniform magnetic flux generated by the magnetic field in the centre of the coil. The magnetic field intensity ranging from 0 to $725 \mu \mathrm{T}$ could be controlled by adjusting the electric current. Currently, $450 \mu \mathrm{T}$ and sinusoidal wave modulation was used to perform the experiments. Because this is a moderately high magnetic flux intensity, when compared with the existing EMFs exposure standards for electromagnetic fields, it may cause harm to human health increasingly depending on the time of exposure. 

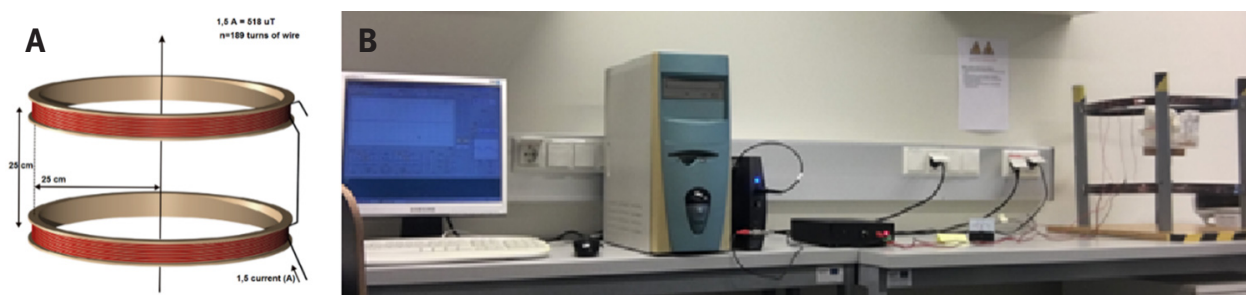

Figure 2. A. The Helmholtz coil, parameters: $R=25 \mathrm{~cm}$, Between the coils $=25 \mathrm{~cm}$, Turns of wire $=189, \mathrm{~B}$. The experimental system generates magnetic field intensity ranging from 0 to $725 \mu$ T could be controlled by adjusting the electric current.

To determine the protective performance of biotextile fabrics with the use of gametic cells the Petri plates with suspension in MS medium (Murasige and Skoog, 1962) of gametic cells were covered with textile specimens including the type of textile material made with incorporated amber yarn and similar material differing from the first type of material by the absence of incorporated amber yarn. Covered with materials of both types, Petri plates with the suspension of gametic cells were placed in the centre of the coil. Besides tested fabrics, a positive control (uncovered Petri dish) was used for comparison purposes. The exposure of gametic cells to $50 \mathrm{~Hz} 450 \mu \mathrm{T}$ irradiation was continued for $2 \mathrm{~h}$.

To study the protective performance of biotextile fabrics such as a classical test organism like D. melanogaster of the Origon laboratory line was used in so-called "Survival test" (Weisman et al., 2014) modified at the Environmental Genetics laboratory of the Institute of Biology, UL. The D. melanogaster larvae (length 1-2 mm) of line Origon were grown on Jazz-Mix food with concentration 18,9 g + $100 \mathrm{~mL}$ $\mathrm{H}_{2} \mathrm{O}$ planting larvae in tubes. Tubes with 30 larva's were covered with different textile specimens made with and without incorporated amber yarn, at least 2 repetitions of each variant were prepared and were placed in the center of the coil. Besides tested fabrics, a positive control (uncovered 2 tubes) was used. The exposure with $50 \mathrm{~Hz}$ magnetic field intensity of $450 \mu \mathrm{T}$ irradiation was continued for 2 generations of $D$. melanogaster. The rate of movement of imago was determined to reflect the overall physiological changes of flies. For the analysis, flies were put to sleep using a $\mathrm{CO}_{2}$ table, imago and dead larvae were counted in each stand and the proportion of male and female flies was determined.

\section{Results and Discussion}

Gametic cells from in vitro culture of $C$. persicum were chosen as a model system in this study because cyclamens were previously (Shabrangi et al., 2010; 
Grauda et al., 2015) found as sensitive to the influence of UV-B and their anthers contain plenty of good quality one nucleus stage gametic cells. Changes in RF in both samples incubated with UV-B and affected by ELF-EMF revealed enhanced protective properties of the tested fabrics when amber is woven into them. This is indicated by an increase in cellular relative fluorescence units (RFU) (brown peak) and a decrease of the fraction of apoptotic cells (blue peak) compared to controls represented by gamete cells incubated without tissue overlay (Figure 3).

The highest survival percentage was found in the group of larvae covered with textile that encompassed amber yarn. The survival of larvae that developed to imago in the group of $D$. melanogaster covered with textile without incorporated amber was lower. No larvae developed to the imago stage in both control (uncovered) groups treated with UV-B. Survival test of $D$. melanogaster demonstrates that the amber yarn increases the protective capacity of biotextile against UV-B irradiation enhancing the percentage of surviving larvae up to $20 \%$ (Figure 4).
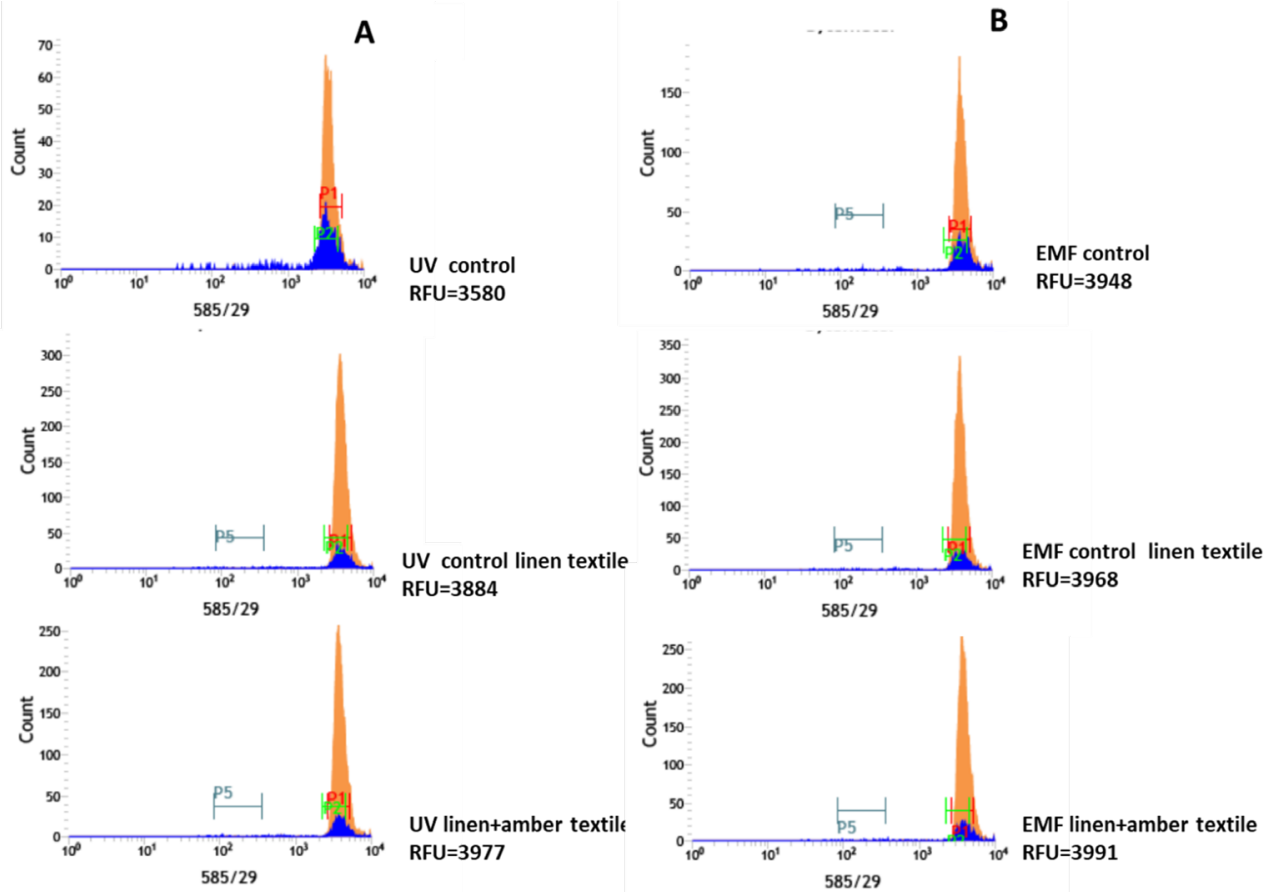

Figure 3. The changes of gametic cells RF depending on the type of fabric after incubation affected by UV-B (A) and impacted by ELF-EMF (B), brown peak shows fluorescence of viable cells, blue indicates apoptotic cell fluorescence. 


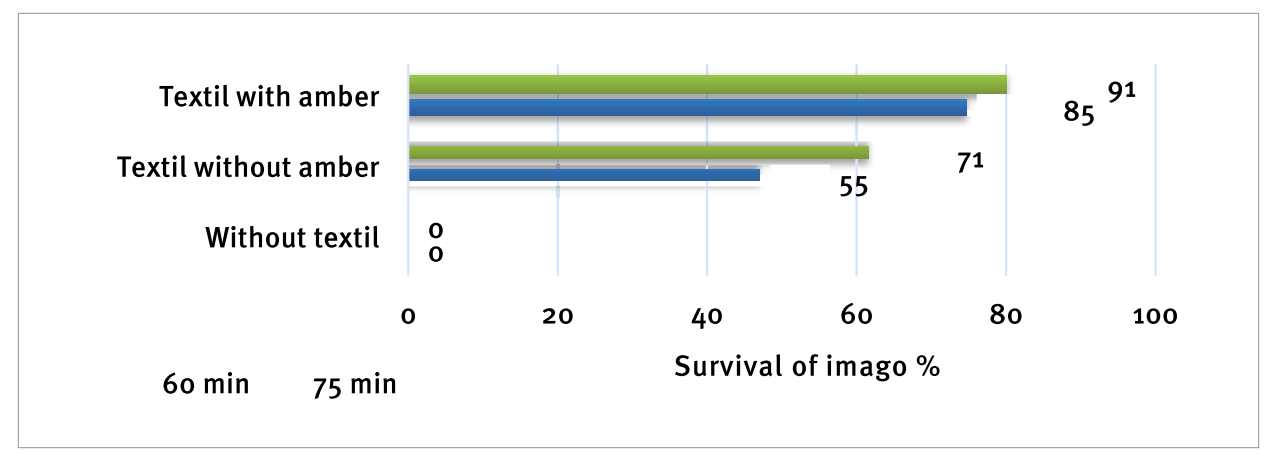

Figure 4. Survival of $D$. melanogaster imago depending on the duration (60 or $75 \mathrm{~min}$.) of UV-B treatment.

Linen textile containing amber micro particles was identified as a material that improved the survivability of $D$. melanogaster grown affected by ELF-EMFs ( $50 \mathrm{~Hz}$, magnetic field $450 \mu \mathrm{T}$ ) by up to $10 \%$, as the structure of cells didn't change in comparison to the absence of protective properties of other tested biotextile specimens (Figure 5).

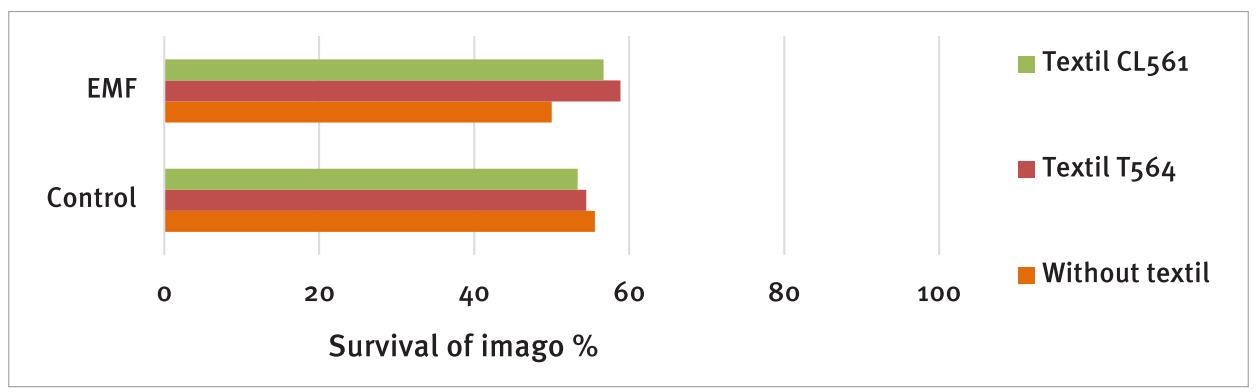

Figure 5. Survival of $D$. melanogaster imago after irradiation with ELF-EMF ( $50 \mathrm{~Hz}$ magnetic field), $450 \mu \mathrm{T}$ (“Textil CL561" - textile with amber; “Textil T564” - textile without amber).

Both bioassay methods presented in the current study were proved as suitable for testing the protective properties of biotextiles against UV and ELF-EMFs irradiation. It should be noted that FCM has several advantages, one being the large number of cells that can be evaluated in a very short time. When measuring changes of cell RF, it is possible to collect and analyse more than 20 parameters from each cell separately. The summarised changes of RFU generate statistically significant results representing the effect on a whole population of cells (Doležel et al., 2007; Dimpka et al., 2012). 
The plant cells have fluorescent pigments which depend on the species and cell specialisation they contain, fluorescent proteins in the chloroplasts, naturally fluorescent products such as proteins, including histones, and cell life process products (You et al., 2015). Fluorescence examination is considered as a standard for screening and diagnostic of early stages of the infection process in plants and changes in reinitiated cell culture; fluorescence would be an indicator of apoptotic cells (Vigneswaran et al., 2009; Martinez et al., 2010; Carter et al., 2013). On the other hand, UV-B irradiation and ELF-EMFs are well known as stress factors that could damage various cells processes. These damages can be classified into two categories - damage to DNA that can cause heritable mutations, and damage leading to disturbance of physiological processes. Certainly, detected increase of cell RF after UV-B irradiation and incubation in ELF-EMFs ( $50 \mathrm{~Hz}$ magnetic field, $450 \mu \mathrm{T}$ ) could be caused by changes in cell metabolism processes and peroxidase complex activity as a responsive reaction on stress factor (Karim et al., 2012; Peykarestan and Seify, 2012). All these factors together determine the cell self-fluorescence, and the method is sufficiently accurate and sensitive to be used to rapidly determine the protective properties of biotextiles.

D. melanogaster survivability test, which was modified for bio-textile testing, indicates the ratio between the number of successfully developed imago and those whose development was stopped. Obtained results show that bio-textile containing amber particles is more efficient at blocking the penetrance of UV-B rays and has a positive influence on the survival of D. melanogaster affected by ELF-EMFs in comparison to the group covered with textile not containing amber particles.

\section{Acknowledgements}

The study was financially supported by the EURECA project E!11170, IFSITEX.

\section{References}

Barnabás, B. 2003. Protocol for producing doubled haploid plants from anthers culture of wheat (Triticum aestivum L.). In: Doubled Haploid Production in Crop Plants. Eds. Maluszymski, Kasha, Forster and Szarejko. Pp. 65-70.

Carter, A. D., Bonyadi, R., and Gifford, M. L. 2013. The use of fluorescence-activated cell sorting in studying plant development and environmental responses. J. Dev. Biol. 57: 545-552.

Dimkpa, C. O., McLean, J. E., Latta, D. E., Manangó, E., Britt, D. W., Johnson, W. P., Boyanov, M. I., and Anderson, A. J. 2012. $\mathrm{CuO}$ and $\mathrm{ZnO}$ nanoparticles; phytotoxicity, metal speciation, and induction of oxidative stress in sand-grown wheat. J Nanopart Res. 14(9): 1-15.

Doležel, J., Greilhuber, J., and Suda, J. 2007. Flow cytometry with plants: an overview. In: Flow cytometry with plant cells. Eds. Doležel, Greilhuber, and Suda. Pp. 41-65. 
Grauda, D., Bumbure, L., Lyashenko, I., Katashev, A., Dekhtyar, Y., and Rashal, I. 2015. Amber particles as living plant cell markers in flow cytometry. Proceedings Latvian Academy Sci. Section B. 69(3): $77-81$.

Grauda, D., Kolodynski, A., Belogrudova, I., Bumbure, L., and Rashal, I. 2015. Combined effects of $50 \mathrm{~Hz}$ electromagnetic field and $\mathrm{SiO} 2$ nanoparticles on oxidative stress in plant's gametic cells. Proceedings Latvian Academy Sci. Section B. 69(3): 82-86.

Karim, Z., Adnan, R., and Ansari, M. S. 2012. Low concentration of silver nanoparticles not only enhances the activity of horseradish peroxidase but alter the structure also. PLoS ONE. 7(7), e41422.

Kasha, K. J., Simon, E., Oro, R., and Shim, Y. S. 2003. Barley isolated microspore culture protocol. In: Doubled Haploid Production in Crop Plants. Eds. Maluszynski, Kasha, Forster and Szarejko. Pp. 43-47.

Lyashenko, I. 2014. Assessment of the impact of amber solution on derma and subcutaneous tissue cell structure. In: Amber Way: Towards the Future of Latvia in the World. Ed. Knēts. Pp. 51-76.

Martinez, M. M., Reif, R. D., and Pappas, D. 2010. Early detection of apoptosis in living cells by fluorescence correlation spectroscopy. Anal. Bioanal. Chem. 396: 1177-1185.

Murashige, T., Skoog, F. 1962. A revised medium for rapid growth and bioassays with tobacco tissue cultures. Physiologia Plantarum. 15: 473-497.

Peykarestan, B., Seify, M. 2012. UV irradiation effects on seed germination and growth, protein content, peroxidaseand protease activity in red bean. International Research Journal of Applied and Basic Sciences. 3(1): 92-102.

Shabrangi, A., Majd, A., Sheidai, M., Nabyouni, M., and Dorranian, D. 2010. Comparing effects of extrremely low frequency electromagnetic fields on the biomass weight of $\mathrm{C} 3$ and $\mathrm{C} 4$ plants in early vegetative growth. Progress In Electromagnetics Research Symposiym Proceedings. Cambrige, USA, July 5-8, pp. 593-598.

Vigneswaran, N., Koh, S., and Gillenwater, A. 2009. Incidental detection of an occult oral malignancy with ultra-fluorescence imaging: A case report. Head Neck Oncol. 1(37). www. headandneckoncology.org/conten/1/1/37

Weisman, N. Y., Fedorov, V. I., and Nemova, E. F. 2014. Survival and life span of Drosophila melanogaster in response to terahertz radiation. Adv Geronto. 4: 87-192.

You, M. K., Lim, S.-H., Kim, M.-J., Jeong, Y. S., Lee, M.-G., and Ha, S.-H. 2015. Improvement of the fluorescence intensity during a flow cytometric analysis for rice protoplasts by localization of a green fluorescent protein into chloroplasts. Int. J. Mol. Sci. 16: 788-804. 


\title{
Adaptation of methods for the determination of biodegradation of bio-textiles with amber particles
}

\author{
Ilze Dubova*1, Agnija Apine', Dace Grauda1', Dalius Butkauskas", \\ Inga Lashenko ${ }^{3}$, Līga Jankevica ${ }^{1}$ \\ 1 Institute of Biology, University of Latvia, Ojära Vācieša street 4, Riga, Latvia, LV-1004 \\ 2 Nature Research Centre, Akademijos Street 2, LT-08412, Vilnius, Lithuania \\ 3 LU Technologies Ltd, Ilūkstes street 107/1-16, Riga, Latvia, LV-1082 \\ * Corresponding author: ilze.dubova@lu.lv
}

\begin{abstract}
One of the criteria for bio-textiles is the potential for biodegradation. Our goal was to adapt methods for the determination of biodegradation of bio-textiles containing amber particles. We adapted methods EN ISO 11721-1: 2001 and ISO 11721-2: 2003 developed for the study of interaction of cellulose - containing textiles and microorganisms.

To determine the changes of fabrics, the mechanical properties and level of biodegradation were examined. Experiments revealing level of biodegradation of bio-textile were carried out at the Institute of Biology, University of Latvia while mechanical properties were tested at the Scientific Laboratory of Mechanics and Bio-textiles of the Institute of Mechanics and Mechanical Engineering, Riga Technical University. The study was financially supported by the EUREKA project E!11170 "Innovative multifunctional bio-textile, integrated with silica dioxide and succinate development, and its impact on biosystems" (IFSITEX).
\end{abstract}

Keywords: deterioration, biofragmentation, soil burial test

\section{Introduction}

One of the criteria for bio-textiles is the potential for biodegradation. Over the last 50 years, global production of synthetic fibres has grown rapidly, which are non-biodegradable and, at best, recyclable, and reusable. Over time, these materials must be incinerated, buried, or disposed of in an aquatic environment, which is not an environmentally friendly solution. Therefore, biodegradation is becoming more and more important as it converts materials into water, carbon dioxide and biomass that do not harm the environment (Arshad et al., 2014). Biodegradation is the process by which a material is physically, chemically, or 
biochemically irreversibly broken down into elements Deterioration of the structure, bio-fragmentation and assimilation accrue during process of biodegradation. It has been studied that cellulose and non-cellulose materials degrade similarly, differing in biodegradation time. During the bio-fragmentation process, microorganisms develop enzymes, as well as free radicals, which break down macromolecules into smaller units (Dulik et al., 2010). Biodegradability of cellulose fibers, as in other textile materials, could be measured by soil burial test, activated sludge test, and enzymatic hydrolysis test (Park et al., 2004). Gaidukovs and coleagues (2016) reported that succinate has an extremely high number of organic compounds of enormous chemical diversity, therefore evaluation of the effect of incorporated amber particles to bio-textiles affecting biodegradability of textiles deserves special attention.

Our goal was to adapt methods for the determination of biodegradation of biotextiles with incorporated amber particles based on modifications of the regular soil burial test ISO 11721-1 (2001), and long-term burial test ISO 11721-2 (2003). The assessment of biodegradation level was based on comparison of fabric changes including mechanical properties (determination of tensile strength) and visual changes of tested specimens.

\section{Materials and methods}

\section{Test specimens}

Fabric stripes of raw materials produced by A/B Linas (LT) \& JLU Technologies Ltd. (LV) were used in tests:

- unfinished - cotton / linen (code CL564T, WARP: linen 28 Tex WEFT: cotton 20 Tex, Twill interlacing)

- bio-textile - cotton / linen with amber particles (code CL561T, WARP: linen 28 Tex, WEFT: cotton 20 Tex plus amber 7.8 Tex, Twill interlacing).

Cotton fabrics were used for control.

The specimens were prepared from the middle of the samples of fabric by cutting the cloth strips lengthwise from the warp direction of the fabric and cut 300 $\mathrm{mm}$ long and $30 \mathrm{~mm}$ wide and then fray down both sides to give a central width of $20 \mathrm{~mm}$. For each fabric 20 test specimens were prepared, 10 for testing without burial and 10 testing after soil burial.

\section{The determination of degradation activity of test soil}

Industrially produced compost mixture (60\% compost, $40 \%$ high bog peat) produced UAB "Juknevičiaus kompostas" (Lithuania) was used. The $\mathrm{pH}$ of the test soil was 6.45 . Water content (WC) $60 \pm 5 \%$ of the water-holding capacity (WHC) of soil mixture was determined by drying the soil sample at the temperature of 
$104 \pm 1{ }^{\circ} \mathrm{C}$ until constant mass is obtained. Calculations and correction of water content of test soil was done before and after test. When the soil was too dry, we added $2.5 \mathrm{ml}$ water on $100 \mathrm{~g}$ soil and replaced any losses during burial test.

Containers - unglazed pottery (15 cm deep) - with $750 \mathrm{~g}$ of soil mixture were used to bury the specimens. In each container were placed 10 specimens in a U-form to evenly contact the soil and container covered with aluminium folia. Incubation was done at $30{ }^{\circ} \mathrm{C} \pm 1{ }^{\circ} \mathrm{C}$ in climatic chamber with $95-100 \%$ humidity. The cloth strips were removed at one-day intervals, lightly rinsed with running tap water, and immersed in $70 \%$ ethanol for 30 min before drying at $45^{\circ} \mathrm{C}$ in thermostat for 24 hours.

\section{The burial of test specimens}

We adapted the regular soil burial test (ISO 11721-1, 2001) and long-term burial test (ISO 11721-2, 2003). The buried fabric strips were removed from containers at intervals of four days for regular burial test and at intervals 8,16 and 28 days for long-term burial test.

To determine the leaching effect on biodegradation, the leaching procedure of test specimens was done before burial procedure according to ISO 11721-1 (2001). The test specimens were held under fresh running tap water at $20 \pm 5{ }^{\circ} \mathrm{C}$ for $24 \mathrm{~h}$ and dried at $45 \pm 5^{\circ} \mathrm{C}$ for $24 \mathrm{~h}$. Test specimens, both leached and unleached were treated in parallel.

All specimens after removing from soil were treated analogous, lightly rinsed with running tap water and immersed in $70 \%$ ethanol for $30 \mathrm{~min}$ before drying at $45^{\circ} \mathrm{C}$ in thermostat for 24 hours.

\section{Determining the breaking strength of buried test specimens}

Mechanical properties of buried and unburied textiles were analysed in Scientific Laboratory of Mechanics and Bio-textiles of the Institute of Mechanics and Mechanical Engineering, Riga Technical University. Breaking strength of the textile samples (after biological degradation) were examined in accordance with EN ISO 13934-1 (2013) on the Universal Testing Machine Zwick / Roell Z150, GE. Zwick / Roell testing machine was used in testing areas of cleanroom class 6 .

\section{Visual evaluation of fabric changes during biodegradation}

Size of buried specimens (width, length, thickness $(\mathrm{mm})$ was tested. The buried specimens were observed using a microscope (magnification 30x and 50x). Colour changes, partial or complete removal of cellulose fibers, appearance in transmitted light, disruption of surface structure is evaluated according to ISO 11721-2 (2003). Comparison was done between corresponding test specimens:

a) unburied unleached with buried unleached;

b) unburied leached with buried leached. 
Fabric changes and the degree of damage were evaluated on a five-point scale, were,

0 - not visible surface structural changes at 50x magnification.

1 - not visible surface structure changes without magnification, but visible under a microscope, light changes in color.

2 - visible surface structure changes without magnification, 25\% surface changes in color and thickness, visible changes in appearance of transmitted light.

3 - visible surface structure damages without magnification, up to $50 \%$ surface changes in color and thickness, visible changes in appearance of transmitted light.

4 - significant surface structure damages without magnification, more than $50 \%$ surface changes in color and thickness, partial removal of cellulose fibers, strong transmitted light.

5 - strong surface structure damages, strong colour changes, complete removal of cellulose fibers, a fabric are fragmented un small parts.

The obtained data were analysed using a Wilcoxon test.

\section{Results and Discussion}

\section{Determining the degradation activity of test soil}

Due to the biological nature of the soil burial test, and the fact that the test soil cannot be precisely standardized, it is only intended to assess the resistance of fabric to micro-organisms after comparing the performance of specimens. We determine the level of microbial soil activity accordingly ISO 11721-1 (2001), using control cotton and linen specimens and a defined incubation period.

Decreasing ratio (\%) in tensile strength of degraded samples was measured by soil burial test and the results are presented in Table 1. The cotton and linen fabric specimens lost more than $80 \%$ from maximum tensile strength after six-day burial. In this experiment, linen showed the highest biodegradability. This may probably be because linen has the largest portion of noncellulose ingredients, including lignin (Parks et al., 2004). 
Table 1. Decreasing ratio (\%) in tensile strength of degraded control samples after incubation in soil $\left(+29^{\circ} \mathrm{C}\right)$

\begin{tabular}{|l|c|c|c|}
\hline \multicolumn{1}{|c|}{ Test specimens } & $\begin{array}{c}\text { Exposure in soil } \\
\text { (days) }\end{array}$ & $\begin{array}{c}\text { Breaking strength, } \\
\text { (P) N } \pm \text { SD }\end{array}$ & Decreasing ratio (\%) \\
\hline cotton fabric & 0, unburied & $88.1 \pm 2.9$ & \\
\hline cotton fabric & 2 & $68.3 \pm 0.9$ & 32.4 \\
\hline cotton fabric & 3 & $53.9 \pm 6.5$ & 39.0 \\
\hline cotton fabric & 4 & $38.7 \pm 10.4$ & 56.1 \\
\hline cotton fabric & 5 & $26.7 \pm 5.3$ & 69.7 \\
\hline cotton fabric & 6 & $16.5 \pm 0.7$ & $\mathbf{8 1 . 3}$ \\
\hline linen fabric & 0, unburied & $212 \pm 8.17$ & 39.6 \\
\hline linen fabric & 3 & $128 \pm 2.2$ & 67.7 \\
\hline linen fabric & 4 & $69 \pm 5.2$ & 77.4 \\
\hline linen fabric & 5 & $48 \pm 4.7$ & $\mathbf{9 1 . 0}$ \\
\hline linen fabric & 6 & $19 \pm 1.3$ & \\
\hline
\end{tabular}

\section{The burial of test specimens}

For the regular burial test, according to determined soil biological activity, we use an incubation period of four days, for long term burial test 8,16 and 28 days. Tensile strength before burial of biotextile with amber particles $(162.6 \mathrm{~N})$ was higher than unfinished $(140.7 \mathrm{~N})$ and controle specimens - cotton fabrics $(84.5 \mathrm{~N})$.

We determined that the tensile strength of biotextile (cotton / linen with amber particles, code CL561) and unfnished (cotton/linen, code T564) before burring procedure did not differ significantly $(P>0.05)$ (Table 2$)$. Tensile strength of cotton, biotextile with amber particles and unfinished specimens after four days of incubations in soil decreased by $57.9 \%, 58.9 \%$ and $65.4 \%$, respectively.

The leaching procedure did not significantly affect the biodegradation processes of cotton fabrics. Leacing of biotextiles with amber particles and unfnished specimens increased loss of tensile strength after four-days burring 1.8-1.9 times (Table 2).

After eight-day biodegradation, cotton fabric specimens had already broken down in pieces, and it was not possible to determine the tensile strength. Tensile strength of unleached bio-textile with amber particles and unfinished specimens after 8 days was in range 2.5-2.7 N. Tensile strength of leached bio-textile with amber particles and unfinished specimens after 8 days was in range 1.2-2.4 N. The presence of amber particles does not significantly affected the biodegradation process as the difference between controls is less than 25\%. After burial fabric specimens in soil 16 and 28 days, fabrics had already broken down in small pieces and only visual evaluation was possible. 
Table 2. The tensile strength of unleached and leached specimens after burial in soil (incubation 4, 8, 16 days)

\begin{tabular}{|c|c|c|c|c|c|}
\hline $\begin{array}{c}\text { Test } \\
\text { specimens }\end{array}$ & $\begin{array}{c}\text { Incubation } \\
\text { period (days) }\end{array}$ & $\begin{array}{l}\text { Breaking } \\
\text { strength } \\
\text { (P) } \mathrm{N} \pm \mathrm{SD} \\
\text { (without } \\
\text { leaching) }\end{array}$ & $\begin{array}{c}\text { Decreasing } \\
\text { ratio (\%) }\end{array}$ & $\begin{array}{c}\text { Breaking } \\
\text { strength } \\
\text { (P) N } \pm \text { SD } \\
\text { (with } \\
\text { leaching) }\end{array}$ & $\begin{array}{c}\text { Decreasing } \\
\text { ratio (\%) }\end{array}$ \\
\hline \multirow{3}{*}{$\begin{array}{l}\text { cotton } \\
\text { fabrics }\end{array}$} & $\begin{array}{l}0 \text { (control, } \\
\text { unburied) }\end{array}$ & $84.5 \pm 6.7$ & & $80.6 \pm 7.2$ & \\
\hline & $4(\mathrm{f} 1)$ & $35.6 \pm 8.9$ & 57.9 & $38.6 \pm 11.7$ & 52.1 \\
\hline & $8(f 2)$ & $\#$ & $\#$ & $\#$ & $\#$ \\
\hline \multirow{3}{*}{$\begin{array}{l}\text { unfinished } \\
\text { (cotton/ } \\
\text { linen) }\end{array}$} & $\begin{array}{l}0 \text { (control, } \\
\text { unburied) }\end{array}$ & $146.1 \pm 7.9$ & & $156.7 \pm 14.7$ & \\
\hline & $4(\mathrm{f} 1)$ & $47.9 \pm 12.3$ & 65.9 & $27.1 \pm 8.8$ & 82.7 \\
\hline & $8(f 2)$ & $2.7 \pm 1.8$ & 99.3 & $2.4 \pm 1.4$ & 99.4 \\
\hline \multirow{3}{*}{$\begin{array}{l}\text { bio-textile } \\
\text { (cotton / } \\
\text { linen with } \\
\text { amber } \\
\text { particles) }\end{array}$} & $\begin{array}{l}0 \text { (control, } \\
\text { unburied) }\end{array}$ & $162.8 \pm 22.7$ & & $154.9 \pm 21.2$ & \\
\hline & $4(\mathrm{f} 1)$ & $67.8 \pm 11.2$ & 58.3 & $34.9 \pm 7.9$ & 77.5 \\
\hline & $8(f 2)$ & $2.5 \pm 1.1$ & 99.6 & $1.2 \pm 0.5$ & 99.4 \\
\hline
\end{tabular}

\section{Visual evaluation of fabric changes during biodegradation}

After four days burial in soil, fabric specimens have changes in surface structure which are visible without magnification. In most cases fabric surface changes in color were in range from $25 \%$ to $50 \%$ (Figure 1). After 8 days using magnification, we were able to observe that microorganisms, including fungi, appeared on the surface of the fibres. Unfinished cotton / linen specimens had more visible fungi than other samples and exhibited the most serious shape deformation caused by fibre damage.

Colour changes, partial or complete removal of cellulose fibres, appearance in transmitted light, disruption of surface structure of buried specimens was evaluated using five - point scale. After visual assessment of the fabric surface structure for samples, the average score obtained after 4 days burial in soil ranged from 1.4 to 2.6 points. Bio-textiles had the lowest surface structure damages - 1.4 points, and significantly differ $(P<0.05)$ from other specimens. 
Fabric specimen surface damage estimates ranged from 2.8 to 3.8 points after 8 days of burial and from 3.6 to 4.6 points after 16 days burial. After 28 days all specimens had strong surface structure damages and ranged from 4.8 to 5.0 points. After 8 days we were able to observe that microorganisms including fungi appeared on the surface of the fibres. Unfinished cotton / linen specimens have more visible fungi than other samples and exhibited the most serious shape deformation caused by fiber damage. We did not observe significant differences between specimens after burial 8,16 and 28 days.
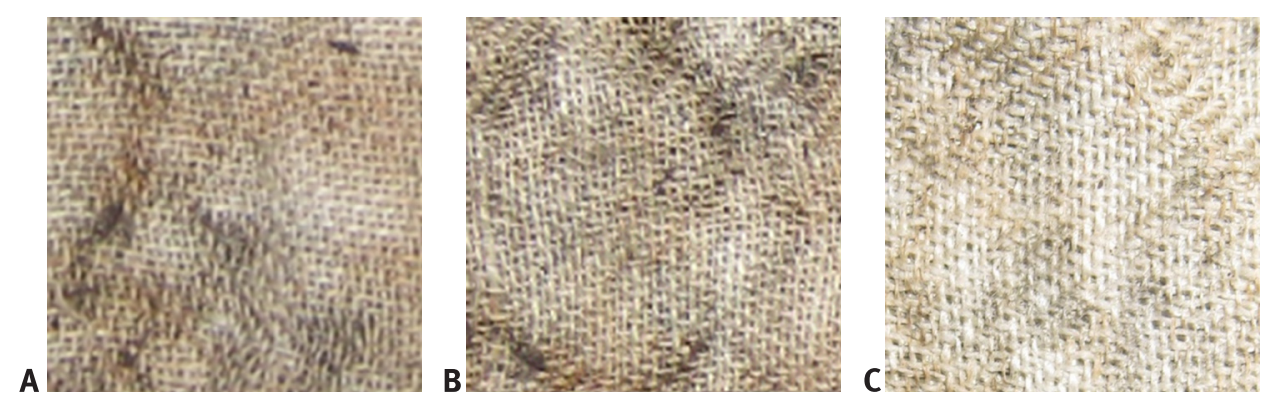

Figure 1. Visual changes of test specimens buried in soil for 4 days $\left(29^{\circ} \mathrm{C}, 95-100 \%\right.$ humidity). Test specimens: A - cotton fabrics; B - unfinished specimens (cotton/linen; code T564); C - bio-textile specimens (cotton /linen with amber particles, code CL561).

The performed experiments showed that the selected methods could be successfully used for determination of biodegradability of new developed materials inciuding bio-textile fabric with incorporated amber particles. Both selected methods (determination of tensile strength and visual evaluation of fabric surface changes during biodegradation) showed that the biodegradation of bio-textiles is significantly lower after four days. The biodegradability of the textiles over a longer period does not differ significantly between the tested specimens.

Although this study provides positive results on the biodegradation of bio-textiles with amber particles, further research is needed on the practical applicability of amber in the production of bio-textiles.

\section{Acknowledgements}

The study was financially supported by the EUREKA project E!11170 "Innovative multifunctional bio-textile, integrated with silica

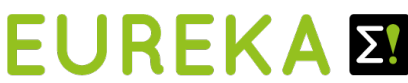
innovation across borders biosystems" (IFSITEX!). 


\section{References}

Arshad, K., Mujahid, M. 2011. Biodegradation of Textile Materials. Boras: The Swedish School of Textiles, pp. 14-22.

Dulik, F., Janda, K., and Wypych, G. 2010. Handbook of Material Biodegradation, Biodeterioration, and Biostablization. $1^{\text {st }}$ Edition. Toronto: ChemTec Publishing, pp. 15-19.

Gaidukovs, S., Lyashenko, I., Rombovska, J., and Gaidukova, G. 2016. Application of amber filler for production of novel polyamide composite fiber. Textile Research Journal. 86(20): 2127-2139.

ISO 11721-1:2001. Textiles - Determination of resistance of cellulose-containing textiles to microorganisms - Soil burial test - Part 1: Assessment of rot-retardant finishing. P. 16.

ISO 11721-2:2003. Determination of the resistance of cellulose-containing textiles to microorganisms - Soil burial test - Part 2: Identification of long-term resistance of a rot retardant finish. P. 7.

ISO 13934-1: 2013. Textiles - Tensile properties of fabrics -Part 1. Determination of maximum force and elongation of maximum force at maximum force using the strip method.

Park, C. H., Kang, Y. K., and Im., S. S. 2004. Biodegradability of Cellulose Fabrics. Journal of Applied Polymer Science. 94: 248-253. 


\title{
Genetic diversity of populations of the rare species Cypripedium calceolus L. in Belarus
}

\section{Natalia Samokhvalova}

Central Botanical Garden of the National Academy of Sciences of Belarus, Surganov street $2 \mathrm{~V}$, 220012, Minsk, Republic of Belarus

E-mail: samakhvalava@cbg.org.by

\begin{abstract}
Studying the level and structure of the genetic diversity of rare species is important for creating an effective strategy for their conservation. Using iPBS markers in our study, it was found that $C$. calceolus genotypes have a rather low level of genetic diversity. Genetic differentiation was found mainly within coenopopulations, which may be caused by the phenomenon of cross-pollination. The genetic distance between coenopopulations corresponded to their geographic location.
\end{abstract}

Keywords: iPBS, genetic diversity

\section{Introduction}

Loss of habitat that can be caused by human activities is a serious threat to the viability of plant populations, which can lead to their decline and extinction (Minasiewicz et al., 2018).

Studying the level and structure of the genetic diversity of rare species is important for creating an effective strategy for their conservation. Genetic diversity is essential for the development of populations, and its loss is often associated with inbred depression, which increases the risk of population extinction (Frankham, 2012). In addition to inbreeding, factors other than inbreeding can affect genetic diversity and population structure. These include the mating system, methods of pollination and seed distribution, life cycle, habitat specifics, landscape, and/or climate change (John et al., 2019).

The selection of specific populations for conservation is usually based on their contribution to the overall genetic diversity of the species. For this reason, it is important to know the degree to which populations differ from each other and the level of genetic diversity within populations. High intrapopulation genetic diversity is an important criterion when choosing priority populations for species 
conservation. In addition to contributing to overall genetic diversity, sufficiently high intrapopulation genetic variability is critical for the long-term survival of a population and the ability to adapt to environmental changes (Guo et al., 2019). The investigation aims to study the level and structure of the genetic diversity of the coenopopulations of Cypripedium calceolus L. growing in Belarus using molecular iPBS markers.

\section{Materials and methods}

Ladies' slipper (Cypripedium calceolus L.) is a perennial short-rhizome plant with a straight leafy stem $15-50 \mathrm{~cm}$ high. The flowers are large, $6-8 \mathrm{~cm}$ in diameter, with a plump lip, similar to a shoe. $C$. calceolus reproduces by vegetative and seed methods, like most members of the orchid family, the mycosymbiont. The area covers most of Europe (except for the south). A relict in origin species of the Euro-Siberian subtaiga, located on the territory of Belarus in isolated places of the European fragment of the range. It has III national protection category (according to the IUCN scale: VU - vulnerable species). Included in Appendix II to the CITES Convention, included in Appendix I to the Berne Convention, and Appendix II to the European Union Habitats Directive. Protected in Ukraine, the Russian Federation (including the Smolensk region), Poland, Lithuania, and Latvia (Kachanovsky, 2015).

In 2020, field studies were carried out in the southern part of the Republic of Belarus to determine the vitality status of $C$. calceolus coenopopulations. Three habitats were examined in the "Divin - Velikiy Les" reserve (DV1, DV2, DV3), located in the island calciphyte localities. These places of growth of the coenopopulation were described in detail in the monograph by N. V. Mikhalchuk (Mikhalchuk, 1997). The fourth habitat is also located in an island location at a sufficient distance from "Divin", on the territory of the "Vygonoshchanskoye" (VG) reserve (Figure 1). The islands of the "Divin" nature reserve are distinguished by great floristic diversity and greater anthropogenic disturbance. The coenopopulation of the "Vygonoshchanskoe" reserve is characterized by a close to the natural character of vegetation, the closeness of the tree layer, and high soil moisture. All four coenopopulations are located at the ecological optimum.

To determine the level of genetic diversity of four coenopopulations of C. calceolus, we used molecular markers iPBS (Kalendar et al., 2010). The iPBS amplification method relies on the almost universal presence of a complementary tRNA sequence as a reverse transcriptase primer binding site (PBS) in LTR retrotransposons. This method is excellent for assessing population diversity due to its high reliability and reproducibility of results, the ability to detect a large number of polymorphic fragments, and relatively low cost (Kalendar et al., 2010). In addition, since iPBS does 
not require any prior knowledge of target sequences, this marker is especially suitable for rare orchids, for which molecular genetic studies have been scarce.

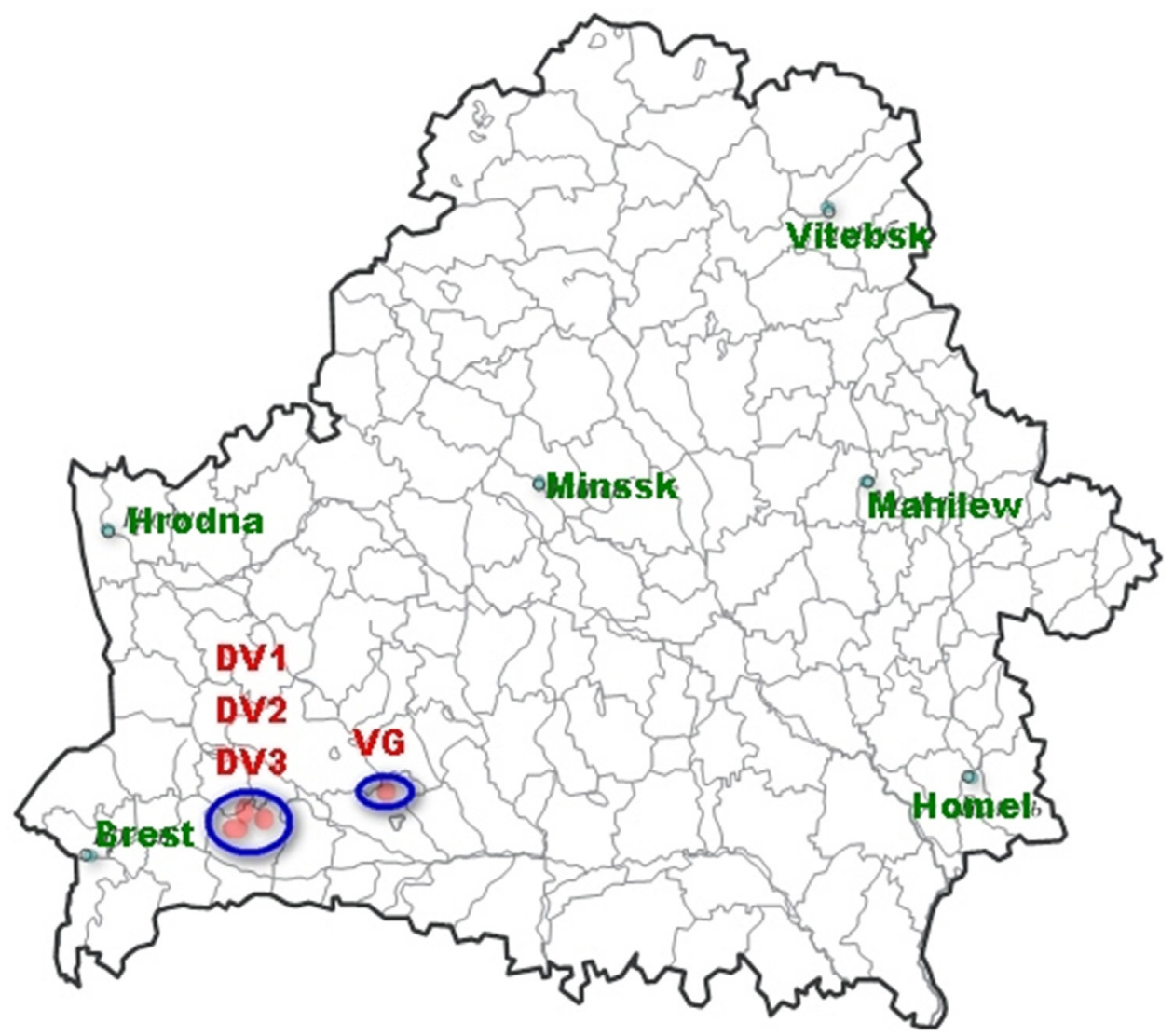

Figure 1. Distribution map of four studied coenopopulations of $C$. calceolus (DV1, DV2, DV3, VG) on the territory of the Republic of Belarus.

Total genomic DNA was isolated from dried leaf tissues by the hexadecyltrimethylammonium bromide (CTAB) method (Devi et al., 2013). The concentration and quality of the isolated DNA were examined and controlled using a NanoPhotometer nucleic acid analyzer (Pearl Implen GmbH, Germany). DNA extracts were diluted to $50 \mathrm{ng} / \mu \mathrm{l}$ for amplification by polymerase chain reaction (PCR).

For the study, 30 markers were used which were proposed by R. Kalendar et al. PCR was carried out in $25 \mu \mathrm{l}$ of a reaction mixture containing 40-50 ng of DNA, $5 \mu \mathrm{l}$ of a ScreenMix PCR ready mixture (Evrogen), $1 \mathrm{mM}$ primer for 12-13 bp. primers or $0.6 \mathrm{mM}$ for $18 \mathrm{bp}$. primers, and water. The PCR program consisted of 1 cycle at $95{ }^{\circ} \mathrm{C}$ for $5 \mathrm{~min}$; 34 cycles at $95{ }^{\circ} \mathrm{C}$ for $15 \mathrm{~s}, 50-60{ }^{\circ} \mathrm{C}$ (depending on 
primer) for $60 \mathrm{~s}$ and $68^{\circ} \mathrm{C}$ for $60 \mathrm{~s}$; final elongation $72{ }^{\circ} \mathrm{C}$ for $5 \mathrm{~min}$. Amplification was performed in a $\mathrm{C} 1000$ Touch Thermal Cycler programmable thermostat (M) Research Inc., Bio-Rad Laboratories, USA). Electrophoresis was carried out at a voltage of $65 \mathrm{~V}$ for 4.5 hours in a $2 \%$ agarose gel. The gel was stained with ethidium bromide for 30 minutes and visualized using the UV Imager Gel Doc XR + system (Bio-Rad, USA).

To create a binary data matrix using the PyElph 1.4 program, the resulting DNA amplicons were recorded as present (1) or absent (0). The binary data matrix was analyzed using POPGEN v. 1.31 to estimate the parameters of genetic diversity, including the percentage of polymorphic bands $(\mathrm{P})$, effective $(\mathrm{Ne})$ and observed number of alleles $(\mathrm{Na})$, Nei genetic diversity $(\mathrm{He})$, Shannon Information Index (I), total gene diversity $(\mathrm{Ht})$, gene flow $(\mathrm{Nm})$, gene diversity in populations $(\mathrm{Hs})$, coefficient of genetic differentiation $(\mathrm{Gst}=[\mathrm{Ht}-\mathrm{Hs}] / \mathrm{Ht})$ and gene flow between populations $(\mathrm{Nm})$. The calculation of the polymorphism information content (PIC), the average genetic distance, and analysis of molecular variance (AMOVA) were performed using the GenALEx 6.5 package. For cluster analysis of UPGMA, the SplitsTree 5 software was used.

\section{Results and discussion}

Markers 2375, 2239, 2374, 2076, 2390, and 2270 were selected to study the genetic diversity and genetic differentiation of C. calceolus, as they allowed to obtain clear DNA fragments with polymorphic loci.

For the iPBS markers used, such indicators as the number of polymorphic loci, their proportion, and the polymorphism information content (PIC) were established (Table 1).

Table 1. Characteristics of selected iPBS markers

\begin{tabular}{|l|c|c|c|c|}
\hline IPBS marker & Number of loci & $\begin{array}{c}\text { Number of } \\
\text { polymorphic } \\
\text { loci }\end{array}$ & $\begin{array}{c}\text { Proportion of } \\
\text { polymorphic } \\
\text { loci (\%) }\end{array}$ & PIC \\
\hline 2375 & 8 & 5 & 62.5 & 0.15 \\
\hline 2239 & 18 & 16 & 88.9 & 0.2 \\
\hline 2374 & 12 & 11 & 91.7 & 0.16 \\
\hline 2076 & 11 & 9 & 81.8 & 0.16 \\
\hline 2390 & 14 & 9 & 64.3 & 0.12 \\
\hline 2270 & 25 & 23 & 92.0 & 0.28 \\
\hline Total & 14.7 & 12.2 & 83.0 & 0.17 \\
\hline
\end{tabular}


Per primer, from 8 to 25 loci and from 5 to 23 polymorphic loci were obtained. The average number of loci and polymorphic loci for all primers was 14.7 and 12.2, respectively. On average, $83 \%$ of all detected loci were polymorphic. The maximum value of the measure of information polymorphism (PIC) was obtained for the marker 2270 (0.28), and the minimum for the marker 2390 (0.12). The PIC value for dominant markers ranges from 0 to 0.5 (Roldán-Ruiz et al., 2000), therefore all selected markers are informative and can be used to assess the genetic diversity of C. calceolus.

The obtained results of the analysis of genetic polymorphism in various habitats of C. calceolus, such as effective ( $\mathrm{Ne}$ ) and observed number of alleles $(\mathrm{Na})$, Shannon information index (I), and Nei genetic diversity $(\mathrm{He})$ are presented in Figure 2.

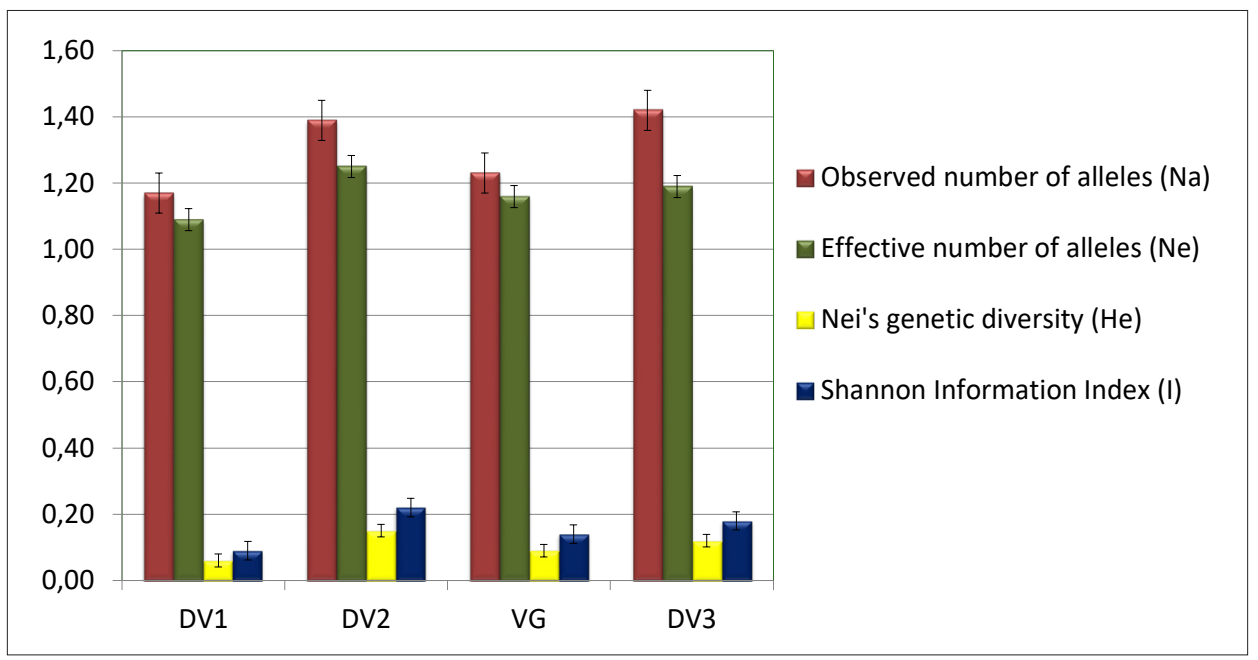

Figure 2. Parameters of genetic polymorphism of the studied coenopopulations (DV1, DV2, DV3, VG) of C. calceolus.

The results showed that in the four coenopopulation studied the observed number of alleles $(\mathrm{Na})$ ranged from 1.17 in the DV1 coenopopulation to $1.42 \mathrm{in}$ the DV3 coenopopulation. The maximum effective number of alleles (1.25) was found in the DV2 coenopopulation, and the smallest number (1.09) was found in the DV1 coenopopulation. Based on the (He) and (I) values the DV1 coenopopulation showed the lowest genetic diversity while the DV2 coenopopulation showed the highest genetic diversity.

Analysis of the interpopulation and intrapopulation genetic structure showed that the total genetic diversity $(\mathrm{Ht}=0.19 \pm 0.04)$ differs from the intrapopulation genetic diversity $(\mathrm{Hs}=0.1 \pm 0.02)$. The level of genetic differentiation among 
the studied coenopopulations of C. calceolus (Gst) was 0.45 with effective gene flow observed between coenopopulations $(\mathrm{Nm}=0.61)$. According to Nei (Nei, 1978), Gst is classified as low if Gst $<0.05$, medium when $0.05<$ Gst $<0.15$, and high when Gst $>0.15$. Thus, the Gst coefficient for C. calceolus (Gst $=0.45)$ would be considered high. The Nm value of gene flow is less than $1(\mathrm{Nm}=0.61)$, which indicates that our selected coenopopulations are subject to genetic drift since it is believed that when $\mathrm{Nm}>1$, gene flow can prevent genetic differentiation between coenopopulations caused by genetic drift (Yan et al., 2019).

Pairwise matrix and Nei genetic distance (Table 2) also show genetic differences between four coenopopulations from different regions analyzed in our study.

Table 2. Pairwise matrix of genetic similarities PhiPT (above the diagonal) and Nei genetic distance (below the diagonal)

\begin{tabular}{|l|c|c|c|c|}
\hline Coenopopulation & DV 1 & DV 2 & VG & DV 3 \\
\hline DV1 & - & 0.89 & 0.85 & 0.95 \\
\hline DV2 & 0.14 & - & 0.9 & 0.91 \\
\hline VG & 0.19 & 0.14 & - & 0.85 \\
\hline DV3 & 0.06 & 0.11 & 0.18 & - \\
\hline
\end{tabular}

This matrix showed that the largest value of Nei's genetic distance (0.19) was observed among the DV1 and VG coenopopulations, and the smallest between the DV1 and DV3 coenopopulations. This was also confirmed by the UPGMA results (Figure 3), based on Ney's distance matrix data, which demonstrate the genetic remoteness of the VG coenopopulation from the rest, which corresponds to its geographic location. The DV1 and DV3 coenopopulations are closest to each other and Nei's genetic distance between them is the smallest.

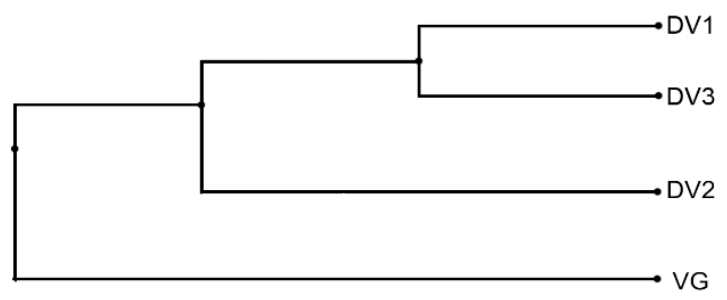

Figure 3. UPGMA dendogram (based on Ney's genetic distance) showing the relationship between the four coenopopulations studied (DV1, DV2, DV3, VG). 
Genetic differentiation between coenopopulations in AMOVA is determined using the PhiPT value (an analogue of the F-test in ANOVA), which calculates coenopopulation differentiation based on the genotypic variance of binary data (Meirmans, 2012). Phi $>0.2$ means that the coenopopulations differ significantly (Resmi et al., 2016).

AMOVA showed that most genetic diversity occurs within coenopopulations (71\%), while genetic diversity between coenopopulations is $29 \%$. The difference between individuals in the coenopopulations was statistically significant with a P-value $<0.001$. The resulting PhiPT value $=0.29$ indicates a high level of genetic differentiation among populations (Table 3). Intrapopulation genetic diversity was expected to be higher than interpopulation genetic diversity, as this distribution is a common feature of cross-pollinated species (Paschoa et al., 2018).

Table 3. AMOVA results for coenopopulations of $C$. calceolus

\begin{tabular}{|l|c|c|c|c|c|c|}
\hline \multicolumn{1}{|c|}{ Source } & df & SS & MS & Est. Var. & PhiPT & \% \\
\hline Total & 18 & 164.53 & - & 5.26 & & - \\
\cline { 1 - 5 } $\begin{array}{l}\text { Between } \\
\text { coenopopulations }\end{array}$ & 3 & 55.31 & 18.44 & 2.92 & \multirow{2}{*}{0.29 ** } & 0.29 \\
\cline { 1 - 5 } $\begin{array}{l}\text { Within } \\
\text { coenopopulations }\end{array}$ & 15 & 109.21 & 7.28 & 7.28 & & 0.71 \\
\hline
\end{tabular}

Note. ${ }^{* \star}$ - differences are significant at a significance level of $P<0.01$.

In general, the results obtained demonstrate that IPBS markers are suitable for studying the genetic diversity of $C$. calceolus, since they efficiently detected polymorphism even in individuals belonging to the same coenopopulation. The results obtained showed that the genotypes of $C$. calceolus studied in this work have a rather low level of genetic diversity. Genetic differentiation was found mainly within coenopopulations, which may be caused by the phenomenon of cross-pollination. Taking into account the obtained data on the similarities and differences between coenopopulations, it can be concluded that the coenopopulations DV1, DV2, and DV3 are a single population. Future studies should focus on more coenopopulations and samples collected from more geographic regions, and use other types of molecular markers in addition to iPBS markers to have better understand the genetic diversity of $C$. calceolus. 


\section{References}

Devi, K. D., Punyarani, K., Singh, N. S., and Devi, H. S. 2013. An efficient protocol for total DNA extraction from the members of order Zingiberales-suitable for diverse PCR based downstream applications. SpringerPlus. 2: 669.

Frankham, R. 2012. How closely does genetic diversity in finite populations conform to predictions of neutral theory? Large deficits in regions of low recombination. Heredity. 108: 167-178.

Guo, J. L., Cao, W. J., Li, Z. M., Zhang, Y. H., and Volis, S. 2019. Conservation implications of population genetic structure in a threatened orchid Cypripedium tibeticum. Plant Diversity. 41: $13-18$.

John, A. L. de W., Mäder, G., Fregonezi, J. N., and Freitas, L. B. 2019. Genetic diversity and population structure of naturally rare Calibrachoa species with small distribution in southern Brazil. Genetics and Molecular Biology. 42: 108-119.

Kachanovsky, I. M. (ed.). 2015. The Red Book of the Republic of Belarus: Plants: The rare and endangered species of wild plants. Belarusian Encyclopedia named after P. Brovki. Minsk, 445 p.

Kalendar, R., Antonius, K., Smýkal, P., and Schulman, A. H. 2010. iPBS: a universal method for DNA fingerprinting and retrotransposon isolation. TAG. Theoretical and Applied Genetics. Theoretische Und Angewandte Genetik. 121: 1419-1430.

Meirmans, P. G. 2012. AMOVA-based clustering of population genetic data. The Journal of Heredity. 103: 744-750.

Mikhalchuk, N. V. 1997. Scientific Substantiation of the organization of the biological reserve "Divin - Velikiy Les". Brest, 17 p.

Minasiewicz, J., Znaniecka, J. M., Górniak, M., and Kawiński, A. 2018. Spatial genetic structure of an endangered orchid Cypripedium calceolus (Orchidaceae) at a regional scale: limited gene flow in a fragmented landscape. Conservation Genetics. 19: 1449-1460.

Nei, M. 1978. Estimation of average heterozygosity and genetic distance from a small number of individuals. Genetics. 89: 583-590.

Paschoa, R. P., Christ, J. A., Valente, C. S., Ferreira, M. F. da S., Miranda, F. D. de, Garbin, M. L., Carrijo, T. T., Paschoa, R. P. da, Christ, J. A., Valente, C. S., Ferreira, M. F. da S., Miranda, F. D. de, Garbin, M. L., and Carrijo T. T. 2018. Genetic diversity of populations of the dioecious Myrsine coriacea (Primulaceae) in the Atlantic Forest. Acta Botanica Brasilica. 32: 376-385.

Resmi, L., Nair, A. R., and Nair, A. S. 2016. Population genetic structure and diversity analysis of South Indian banana cultivars. Journal of Plant Breeding and Crop Science. 8: 1-12.

Roldán-Ruiz, I., Dendauw, J., Van Bockstaele, E., Depicker, A., and De Loose, M. 2000. AFLP markers reveal high polymorphic rates in ryegrasses (Lolium spp.). Molecular Breeding. 6: 125-134.

Yan, W., Li, J., Zheng, D., Friedman, C., and Wang, H. 2019. Analysis of genetic population structure and diversity in Mallotus oblongifolius using ISSR and SRAP markers. Peer J. 7: e7173. 


\title{
Elemental composition of seeds of representatives of the genus Turbinicarpus (Backeb.) Buxb. et Backeb.
}

\section{Tatsiana Shlapakova}

Central Botanical Garden of the National Academy of Sciences of Belarus, Surganov street 2v, 220012, Minsk, Republic of Belarus

E-mail:T.Shlapakova@cbg.org.by

\begin{abstract}
The article presents data on the elemental composition of seeds of species of the genus Turbinicarpus. The study of the content of chemical elements in seeds makes it possible to explain their species-specificity, which can be used as one of the systematic characteristics of the studied group of plants.
\end{abstract}

Keywords: Chemical elements, scanning electron microscopy

\section{Introduction}

Electron microscopy with electron probe chemical analysis makes it possible to find out the elemental composition of seeds of the studied species and to carry out their quantitative analysis. In works Sorokopudov (Sorokopudov et al., 2012) and Tokhtar (Tokhtar et al., 2012) differences in the percentage of individual chemical elements in different parts of fruits and seeds were found. Belopukhov (Belopukhov et al., 2012) divided chemical elements into groups depending on their percentage in plants, which also makes it possible to use this as a systematic trait.

Turbinicarpus (Backeb.) Buxb. et Backeb is a genus of Mexican cacti which, according to Hunt et al. (Hunt et al., 2006) includes 16 species and 21 subspecies; however, the number of species and subspecies varies among authors (Anderson, 2001; Donati and Zanovello, 2005). Turbinicarpus extends in the northeastern region of the Republic of Mexico (in the Sonoran and Highland Mexican provinces of the Holarctic Kingdom (northeastern regions of Mexico, in particular, the states of San Luis Potosi, Guanajuato, Nuevo Leon, Queretaro, Hidalgo, Coahuila, Tamaulipas, and Sac). Due to illegal harvesting, changes in soil use, and overgrazing, all species of the genus, except for T. horripilus, are listed in NOM-059-SEMARNAT 2010. In addition, all species of this genus are included 
in Appendix I of CITES (Hunt et al., 2016) and the Red List of the International Union for Conservation of Nature (Duarte et al., 2015).

Turbinicarpus have a spherical or slightly flattened stem that varies in color from grayish to brown (Figure 1). The height and diameter of representatives of this genus vary from $1.5 \mathrm{~cm}$ to $12-14 \mathrm{~cm}$. The ribs are divided into tubercles. The tubercles are pronounced, rounded, located in a spiral. The spines are usually in the form of papery, hair-like, or feathery structures. Areolae are covered with white hairs. Plants have a turnip root, which accumulates not only moisture but also nutrients, it penetrates very deeply into the substrate and becomes thinner to the lower part. The flower is sessile, $0.7-3.8 \mathrm{~cm}$ long. The color of the perianth varies by species and subspecies and can be white, yellow, red, pink, or purple. Numerous stamens grow together with the perianth. Ripe fruits are $0.4-1.8 \mathrm{~cm}$ long, berry-like, and fleshy. Seeds are 1-1.5 mm long, black or red (Mario, 2004).
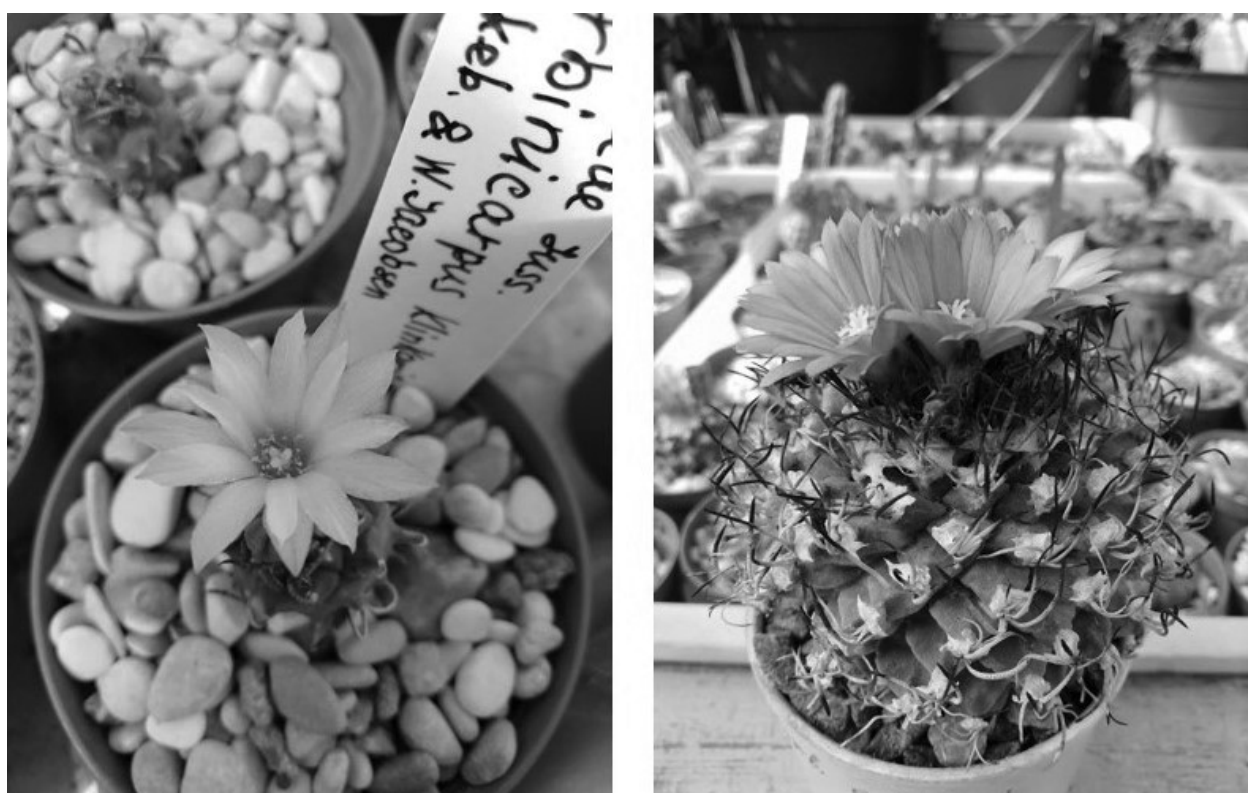

Figure 1. T. schmiedickeanus subsp. klinkerianus (Backeb. \& W. Jacobsen) Glass \& R. A. Foster and T. alonsoi Glass \& S. Arias.

Thus, the study of all aspects of the growth of this plant will lead to a more specific plan for conservation and restoration in habitats and botanical gardens. One of these aspects is the study of the structure and composition of seeds. The study aims to establish the elemental composition of seeds of the genus Turbinicarpus. 


\section{Materials and methods}

The objects of the study were seeds of 43 species of the genus Turbinicarpus. These are seeds of own reproduction of the Central Botanical Garden of the National Academy of Sciences of Belarus, as well as attracted seed material. The studies were carried out by scanning electron microscopy with electron probe chemical analysis using a JSM-5610 LV scanning electron microscope with an EDX JED-2201 chemical analysis system.

\section{Results and discussion}

The study established the mass fractions (\%) of the following chemical elements: $\mathrm{Na}, \mathrm{P}, \mathrm{Cl}, \mathrm{S}, \mathrm{Si}, \mathrm{Al}, \mathrm{Ca}, \mathrm{Mg}, \mathrm{K}$ (Table 1).

Table 1. Weight fraction (\%) of chemical elements in seeds Turbinicarpus

\begin{tabular}{|c|c|c|c|c|c|c|c|c|c|}
\hline Species (adopted names) & $\mathrm{Na}$ & Mg & Al & Si & $P$ & S & $\mathrm{Cl}$ & K & $\mathrm{Ca}$ \\
\hline $\begin{array}{l}\text { T. schmiedickeanus subsp. } \\
\text { klinkerianus (Backeb. \& W. } \\
\text { Jacobsen) Glass \& R. A. Foster }\end{array}$ & 0.65 & 1.29 & 0.84 & 0.59 & 0.08 & 0.62 & 0.99 & 8.40 & 1.55 \\
\hline T. klinkerianus "lilinkeuiduus" & 0.59 & 0.63 & 0.95 & 0.87 & 0.2 & 0.56 & 0.33 & 5.39 & 3.77 \\
\hline $\begin{array}{l}\text { T. lophophoroides (Werderm.) } \\
\text { Buxb. \& Backeb. }\end{array}$ & 0.24 & 1.5 & 1.11 & 0.29 & 0.47 & 0.58 & 0.31 & 6.75 & 2.51 \\
\hline $\begin{array}{l}\text { T. lophophoroides } \\
\text { f. roseiflorus }\end{array}$ & 0.55 & 3.34 & 0.71 & 3.68 & 0.34 & 0.37 & 0.45 & 10.12 & 2.82 \\
\hline $\begin{array}{l}\text { T. pseudomacrochele subsp. } \\
\text { lausseri (Diers \& G. Frank) } \\
\text { Glass }\end{array}$ & - & 0.65 & 0.78 & 0.31 & 0.23 & 0.19 & 0.08 & 7.48 & 2.36 \\
\hline $\begin{array}{l}\text { T. schmiedickeanus subsp. } \\
\text { andersonii Mosco }\end{array}$ & 1.01 & 0.82 & 0.81 & 0.4 & 0.01 & 0.20 & 0.06 & 2.2 & 2.62 \\
\hline $\begin{array}{l}\text { T. schmiedickeanus subsp. } \\
\text { flaviflorus (G. Frank \& } \\
\text { A.B. Lau) Glass \& R. A. Foster }\end{array}$ & 0.62 & 0.35 & 0.18 & 0.39 & 0.15 & 0.23 & 0.47 & 4.35 & 1.91 \\
\hline T. graminispinus Matusz. & - & 2.7 & 2.6 & 0.38 & - & 0.33 & 0.01 & 3.03 & 5.86 \\
\hline T. hoferi Lüthy \& A. B. Lau & 0.44 & 0.90 & 0.19 & 0.34 & 0.23 & 0.15 & 0.11 & 2.95 & 2.56 \\
\hline T. jauernigii G. Frank & 0.41 & 1.29 & 0.80 & 0.51 & 0.44 & 0.45 & 0.21 & 4.82 & 2.77 \\
\hline $\begin{array}{l}\text { T. pseudopectinatus } \\
\text { v. albiflorus }\end{array}$ & - & 0.54 & 0.78 & 1.25 & 0.19 & 0.42 & 2.31 & 6.25 & 2.04 \\
\hline
\end{tabular}




\begin{tabular}{|c|c|c|c|c|c|c|c|c|c|}
\hline Species (adopted names) & $\mathrm{Na}$ & Mg & Al & Si & $\mathbf{P}$ & $\mathrm{S}$ & $\mathrm{Cl}$ & K & $\mathrm{Ca}$ \\
\hline $\begin{array}{l}\text { T. pseudopectinatus } \\
\text { v. rubriflorus }\end{array}$ & 1.99 & 0.40 & 1.82 & 0.80 & 0.10 & 0.48 & 0.54 & 3.63 & 2.76 \\
\hline $\begin{array}{l}\text { T. valdezianus (Møller) Glass } \\
\text { \& R. A. Foster }\end{array}$ & 0.37 & 0.07 & 1.91 & 2.32 & 0.05 & 0.80 & 0.36 & 10.3 & 2.88 \\
\hline T. valdezianus v. albiflorus & 0.12 & 0.36 & 2.34 & 0.62 & - & 0.64 & 0.62 & 15.16 & 2.72 \\
\hline $\begin{array}{l}\text { T. zaragozae (Glass \& } \\
\text { R. A. Foster) Glass \& Hofer }\end{array}$ & 2.67 & 0.49 & 1.34 & 2.88 & 0.38 & 0.27 & 0.34 & 4.62 & 6.36 \\
\hline $\begin{array}{l}\text { T. schmiedickeanus subsp. } \\
\text { bonatzii (G. Frank) Panar. }\end{array}$ & - & 0.74 & 2.24 & 1.59 & 0.37 & - & 0.31 & 6.57 & 1.50 \\
\hline T. schwarzii (Shurly) Backeb. & 0.10 & 3.20 & 0.88 & - & 0.03 & 0.04 & 0.19 & 9.96 & 1.50 \\
\hline $\begin{array}{l}\text { T. schwarzii v. rubriflorus } \\
\text { Gerhart Frank }\end{array}$ & 0.17 & 1.24 & 0.70 & 0.63 & 0.05 & 0.37 & 0.22 & 5.53 & 2.05 \\
\hline T. spacellatus & 0.38 & 0.53 & 0.78 & 1.45 & 0.43 & 0.45 & 0.42 & 2.97 & 7.43 \\
\hline T. $\times$ mombergeri Riha & 0.93 & 0.6 & 0.93 & 1.46 & 0.27 & 0.23 & 0.78 & 5.64 & 2.29 \\
\hline $\begin{array}{l}\text { T. gielsdorfianus (Werderm.) } \\
\text { John \& Riha }\end{array}$ & 0.38 & 0.8 & 0.84 & 0.15 & 0.11 & 0.29 & 0.22 & 3.96 & 2.64 \\
\hline $\begin{array}{l}\text { T. schmiedickeanus subsp. } \\
\text { gracilis (Glass \& R. A. Foster) } \\
\text { Glass. }\end{array}$ & 0.18 & 0.39 & 1.68 & 0.58 & 0.38 & 0.16 & 0.17 & 5.86 & 3.71 \\
\hline $\begin{array}{l}\text { T. saueri subsp. } \\
\text { knuthianus (Boed.) Lüthy }\end{array}$ & 0.11 & 0.77 & 1.86 & 0.64 & 0.68 & 0.22 & 0.79 & 5.26 & 1.54 \\
\hline $\begin{array}{l}\text { T. pseudomacrochele subsp. } \\
\text { minimus (G. Frank) Lüthy \& } \\
\text { A. Hofer }\end{array}$ & 0.32 & 0.73 & 1.07 & 2.7 & 0.57 & 0.28 & 0.14 & 2.67 & 1.13 \\
\hline T. krainzianus v. lausseri & 0.33 & 0.19 & 1.48 & 1.22 & 0.16 & 0.35 & 0.28 & 4.71 & 0.96 \\
\hline $\begin{array}{l}\text { T. schmiedickeanus subsp. } \\
\text { macrochele (Werderm.) } \\
\text { N. P. Taylor }\end{array}$ & 0.91 & 0.79 & 0.54 & 0.17 & 0.23 & 0.39 & 0.64 & 5.19 & 1.14 \\
\hline T. macrochele v. kupackii & 0.46 & 0.86 & 0.58 & 0.59 & 0.28 & 0.16 & 0.42 & 6.37 & 1.69 \\
\hline T. macrochele v. frailensis & 1.1 & 0.38 & 0.76 & 0.69 & 0.10 & 0.12 & 0.13 & 5.81 & 1.47 \\
\hline T. polaskii Backeb. & 2.1 & 1.5 & 0.85 & 0.24 & 0.87 & 0.47 & 0.51 & 9.48 & 1.79 \\
\hline $\begin{array}{l}\text { T. pseudomacrochele } \\
\text { (Backeb.) Buxb. \& Backeb. }\end{array}$ & 0.06 & 0.65 & 0.84 & 1.31 & 0.46 & 0.29 & 0.47 & 4.58 & 1.52 \\
\hline $\begin{array}{l}\text { T. pseudomacrochele } \\
\text { v. alenae }\end{array}$ & 0.05 & 0.66 & 0.63 & 1.02 & 0.18 & 0.03 & 0.14 & 5.67 & 1.39 \\
\hline
\end{tabular}




\begin{tabular}{|c|c|c|c|c|c|c|c|c|c|}
\hline Species (adopted names) & $\mathrm{Na}$ & Mg & Al & Si & $P$ & $S$ & $\mathrm{Cl}$ & K & $\mathrm{Ca}$ \\
\hline $\begin{array}{l}\text { T. schmiedickeanus subsp. } \\
\text { dickisoniae (Glass \& R. A. } \\
\text { Foster) N. P. Taylor }\end{array}$ & 1.13 & 0.99 & 1.83 & 0.83 & - & 0.48 & - & 4.79 & 1.65 \\
\hline T. swobodae Diers \& Esteves & 0.99 & 1.41 & 2.43 & 1.19 & - & 0.26 & 1.10 & 3.47 & 9.33 \\
\hline $\begin{array}{l}\text { T. saueri subsp. ysabelae } \\
\text { (Schlange) Lüthy. }\end{array}$ & 0.34 & 0.59 & 1.41 & 0.24 & 0.08 & 0.26 & - & 6.64 & 1.86 \\
\hline T. saueri (Boed.) John \& Riha & 2.38 & 1.57 & 0.97 & 0.85 & 0.12 & - & - & 6.69 & 2.54 \\
\hline T. saueri subsp. gonzalezii & 0.99 & 0.63 & 0.97 & 0.73 & 0.26 & 0.21 & - & 5.21 & 1.34 \\
\hline T. beguinii v. senilis $f$. nobile & 3.87 & 1.62 & 2.05 & 1.99 & 0.62 & 0.05 & 0.05 & 6.74 & 6.66 \\
\hline $\begin{array}{l}\text { T. mandragora (Frič ex A. } \\
\text { Berger) A. D. Zimmerman }\end{array}$ & 2.88 & 1.09 & 2.78 & 0.68 & - & 0.20 & 1.14 & 6.68 & 4.27 \\
\hline T. alonsoi Glass \& S. Arias & - & 2.13 & 1.76 & 1.16 & - & 0.54 & - & 10.29 & 2.05 \\
\hline T. laui Glass \& R. A. Foster & 0.58 & 2.34 & 1.35 & - & 0.81 & 0.59 & 0.41 & 7.38 & 3.75 \\
\hline T. roseiflorus Backeb. & 0.48 & 1.11 & 0.22 & 0.75 & 0.15 & 0.33 & 0.41 & 3.87 & 1.1 \\
\hline $\begin{array}{l}\text { T. dickisoniae (Glass \& R. A. } \\
\text { Foster) Glass \& A. Hofer }\end{array}$ & - & 0.82 & 0.82 & 0.99 & 0.19 & 0.6 & 0.3 & 2.66 & 3.74 \\
\hline $\begin{array}{l}\text { T. pseudopectinatus (Backeb.) } \\
\text { Glass \& R. A. Foster }\end{array}$ & 1.04 & 0.16 & 0.65 & 0.58 & 0.22 & 0.57 & 0.59 & 4.31 & 1.05 \\
\hline T. saueri subsp. nelissae & 1.62 & 1.71 & 0.27 & 1.21 & 0.39 & 0.7 & 0.12 & 7.93 & 2.2 \\
\hline
\end{tabular}

These elements can be divided into two groups according to their content: $1^{\text {st }}$ group $-2.5-15.2 \%(\mathrm{~K}, \mathrm{Ca})$ and $2^{\text {nd }}$ group $-0.01-2.5 \%(\mathrm{Na}, \mathrm{P}, \mathrm{Cl}, \mathrm{S}, \mathrm{Si}, \mathrm{Al}, \mathrm{Mg})$. However, it is worth noting the exceptions in these groups. Thus, the weight fraction of $\mathrm{Na}$ in T. beguinii v. senilis $f$. nobile $-3.87 \%$, T. mandragora $-2.88 \%$, T. zaragosae - 2.67\%; $\mathrm{Mg}$ in T. schwarzii - 3.2\%; $\mathrm{Al}$ in T. mandragora $-2.78 \%$; $\mathrm{Si}$ in T. zaragosae $-2.88 \%$; $\mathrm{Ca}$ in T. bonatzii $-1.5 \%$, T. knuthianus $-1.54 \%$, T. pseudopectinatus - 1.05\%, T. polaskii - 1.79\%, T. schmiedickeanus subsp. klinkerianus $-0.42 \%$, T. schwarzii $-1.5 \%$. The highest content was shown by Ca (0.42-9.33\%), K (2.66-15.16), Mg (0.7-3.2\%), P (0.01-0.87\%) - included in phytin the main source of inorganic phosphate in seeds. Calcium in the composition of pectates is part of the cell walls of plants, its presence is important for the normal functioning of membranes, and it is an activator of enzymes also. Potassium is a calcium antagonist, is part of the enzymes involved in the formation of ATP in the process of oxidative phosphorylation, in addition, many enzymes involved in protein synthesis require the presence of potassium. Magnesium supports the structure of ribosomes by binding RNA and protein, is part of chlorophyll, and 
is an activator of many enzymes. Phosphorus is involved in metabolism, cell division, reproduction, the transmission of hereditary properties, and other complex processes occurring in the plant.

The seeds are the units of plants with the most stable characteristics. Therefore, the chemical composition of the seeds can be one of the important characteristics of taxonomy. The activity of most enzymes depends on the content of activators and inhibitors in the cells, which are micro-and macroelements.

This study showed that even within the same genus, species have a different elemental composition of seeds, which indicates the species specificity of this indicator.

Thus, the seeds have a species-specific elemental composition, which can be used as one of the diagnostic features to establish the systematic position of plant seeds obtained from controversial sources.

\section{References}

Anderson, E. F. 2001. The Cactus Family. $1^{\text {st }}$ Edition. Timber Press, Incorporated, Portland, Or. 776 p.

Belopukhov, S. L., Zhevnerov, A. V., Kalabashkina, E. V., and Dmitrevskaya, I. I. 2012. Determination of the micronutrient composition of flax products. Butlerov Readings. 32: 72-75.

Donati, D., Zanovello, C. 2005. Knowing Understanding and Growing Turbinicarpus-Rapicactus. A trip across the mexican states of Coahuila, Guanajuato, Hidalgo, Nuevo Leon, Queretaro... Cactus Trentino Südtirol, Trento. 256 p.

Duarte, J., Vogliotti, A., Cartes, J., and Oliveira, M. 2015. The IUCN Red List of Threatened Species. The IUCN Red List of Threatened Species. 1: 1.

Hunt, D., Taylor, N. and International Cactaceae Systematics Group (eds.). 2006. The New Cactus Lexicon. dh Books, Milborne Port.

Hunt, D. R., K. Royal Botanic Gardens, International Organization for Succulent Plant Study, and Conference of the Parties to the Convention on International Trade in Endangered Species of Wild Fauna and Flora. 2016. C.I.T.E.S Cactaceae Checklist.

Mario, J. M. S. A. A. G. F. R. S. B. 2004. The Genus Turbinicarpus in San Luis Potosi. $1^{\text {st }}$ Edition. Cactus \& Co., Venegono Sup., Italy.

Sorokopudov, V. N., Aldoshkin, I. S., Kolesnikov, D. A., Shestopalova, N. N., and Rybitsky, S. M. 2012. Elemental composition of fruits and seeds of some species and varieties of viburnum in the south-west of the Central Russian Upland. Scientific Bulletin of Belgorod State University. Series: Natural Sciences.

Tokhtar, L. A., Sorokopudov, V. N., and Kolesnikov, D. A. 2012. Elemental Composition of Fruits And Seeds of Red Currant. Scientific Bulletin of Belgorod State University. Series: Medicine. Pharmacy. 